\title{
Estudio de laboratorio sobre utilización de zeolita natural versus zeolita sintética en la fabricación de mezclas semicalientes
}

\section{A comparative study of natural zeolite and synthetic zeolite as an additive in warm asphalt mixes}

\author{
A. Alonso(*), E. Tejeda(*), F. Moreno(**), M. C. Rubio(**), E. Medel(***)
}

\section{RESUMEN}

Las mezclas semicalientes permiten una reducción de la temperatura de fabricación respecto a las mezclas tradicionales, mediante la modificación del proceso de producción en planta o el empleo de aditivos. En esta investigación se analiza el empleo de zeolita natural procedente de Cuba como aditivo para la fabricación de mezclas semicalientes, en comparación con el empleo de zeolitas artificiales. Para ello, a través de pruebas de estabilidad Marshall, sensibilidad al agua y módulos de rigidez se realiza un estudio comparativo. El resultado obtenido mostró un comportamiento similar entre las mezclas con zeolita natural y la sintética, resultando en ambos casos ligeramente inferior al obtenido por la mezcla patrón. Además, se evaluó la influencia de la adición de zeolita natural a la mezcla en diferentes porcentajes, como filler o como arena, obteniendo mejores resultados con la incorporación en la fracción filler.

Palabras clave: mezclas asfálticas semicalientes; zeolitas; impacto ambiental; reducción de emisiones.

\begin{abstract}
Zeolite can be used as an ingredient in warm bituminous mixes to reduce manufacturing temperatures. The zeolite for this purpose is usually synthetic, but natural zeolite can also be used. The research presented in this paper analyzed the use of natural zeolite from Cuba in the form of sand and filler as an additive in warm asphalt mixes and compared it to asphalt mixes with synthetic zeolite. The mixes were given the Marshall tests, and their moisture sensitivity and stiffness modulus values were also obtained. The results showed that both types of mix had a similar performance, which was only slightly lower than that of the reference mix. The use of different dosages of natural zeolite in the mixes gave the best results when the zeolite was incorporated as filler. This study demonstrated that the use of natural zeolite is an effective way of reducing the temperature of bituminous mixes.
\end{abstract}

Key words: half-warm asphalt mixes; zeolite; environmental impact; reduction of emissions.

(*) Instituto Superior Politécnico José Antonio Echeverría (La Habana, Cuba).

(**) Universidad de Granada (Granada, España).

(***) Universidad Politédcnica de Valencia (Valencia, España). 


\section{INTRODUCCIÓN}

Hoy en día la circulación de vehículos por carreteras, es el medio principal de transporte, tanto de personas como de bienes y servicios. Durante las últimas décadas, se ha desatado un aumento considerable de los volúmenes de tráfico, dando paso al incremento de las cargas que llegan al pavimento. De ahí la importancia de buscar alternativas sostenibles para el diseño y construcción de estas estructuras, logrando que sean más duraderas, económicas y amables con el medio ambiente.

La investigación sobre materiales sostenibles implica la obtención de nuevos métodos que puedan tratar aspectos ambientales como el calentamiento global. El impacto provocado por la producción de mezclas asfálticas sobre la calidad del aire se debe fundamentalmente al empleo de altas temperaturas su fabricación en planta y posterior puesta en obra (1).

Para concienciar a los países en la reducción de las concentraciones de gases de efecto invernadero, producido por las emisiones de sustancias como el dióxido de carbono $\left(\mathrm{CO}_{2}\right)$; y atenuar el calentamiento global, se adoptó el Protocolo de Kyoto, en la tercera sesión de la Convención de las Naciones Unidas para el Cambio Climático. Este tratado tiene el propósito de reducir los niveles de emisión de $\mathrm{CO}_{2}$ correspondientes al año 1990, en un 5,2\% entre el 2008 y el $2012(2,3)$. La Unión Europea se planteó la reducción de estas emisiones en un 15\% para el año 2010 $(4,5)$. Por su parte Alemania logró reducir los niveles del año 1990 , en un $25 \%$ en el $2005(6,7)$.

Es por esto, que desde hace varios años la industria asfáltica ha venido desarrollando nuevos productos y procedimientos que conlleven al ahorro energético y la disminución de la contaminación ambiental, los cuales han sido enfocados especialmente en la fabricación de mezclas a temperaturas inferiores a las convencionales (150-180 ${ }^{\circ} \mathrm{C}$ ). Para lograr este objetivo, el propósito más reciente lo constituyen los procesos de Mezclas Asfálticas Semicalientes (Warm Mix Asphalt, WMA).

Varios son los criterios empleados para diferenciar las mezclas bituminosas. La Figura 1 muestra una clasificación de estas atendiendo a la temperatura de fabricación. También se indica el consumo de combustible por tonelada de mezcla para cada tipo y temperatura de producción.

Se denominan mezclas asfálticas semicalientes las que, gracias al empleo de determinados procedimientos, pueden ser fabricadas a temperaturas del orden de los $30^{\circ} \mathrm{C}$ a $40^{\circ} \mathrm{C}$ por debajo de las utilizadas para las mezclas tradicionales en caliente. Los procesos que suelen emplearse son: la doble envuelta, la adición de zeolitas sintéticas, el espumado del betún o la adición de ceras o

\section{INTRODUCTION}

In the world today, road vehicles of all types have become the principal transportation mode for people as well as for goods and services. Not surprisingly, over the last thirty years, the traffic volume on road networks has soared, and this has led to increased loads on pavement surfaces. There is thus a growing need to find sustainable alternatives for the design and construction of roadways, which will increase their useful life and also make them more cost-efficient and environmentally friendly.

Currently, research on sustainable materials focuses on innovative methods that can effectively deal with environmental issues such as global warming. The negative impact of the manufacture of asphalt mixes on air quality is mainly due to the high temperatures at the asphalt plant as well as at the road construction siteduring the spreading of the mix (1).

In 1997, the Kyoto Protocol was adopted in the third session of the United Nations Framework Convention on Climate Change. Many nations signed it in an effort to attenuate global warming by increasing international awareness of the urgent need to reduce greenhouse gas concentrations from the emissions of substances such as carbon dioxide $\left(\mathrm{CO}_{2}\right)$. The objective was to reduce 1990 emission levels of $\mathrm{CO}_{2}$ by $5.2 \%$ in 2008-2012 $(2,3)$. The feasibility of this objective was demonstrated by Germany, a country that in 2005 managed to reduce its 1990 emission levels by $25 \%(4,5)$. In 2010, the European Union approved a $15 \%$ reduction of greenhouse gas emissions $(6,7)$.

In line with these efforts, the asphalt industry has been creating new products and developing new procedures that prioritize energy efficiency along with lower levels of environmental pollution. One of the main focuses of this industry is the manufacture of asphalt mixes at temperatures lower than 150-180 ${ }^{\circ} \mathrm{C}$. In this respect, a recent proposal involves the use of warm asphalt mixes (WMA).

Bituminous mixes can be classified in various ways. Figure 1 shows a classification based on manufacturing temperature. Also shown is the level of fuel consumption per ton for each mix type and temperature level.

Warm asphalt mixes are manufactured at temperature levels that are 30-40 ${ }^{\circ} \mathrm{C}$ lower than those of conventional hot asphalt mixes. The processes used in warm mixes are double coating, foam bitumen, and the use of aerogeneous agents such as zeolite, or of organic additives such as paraffin or other types of wax(8). Furthermore, research on tensoactive products has shown that their performance 


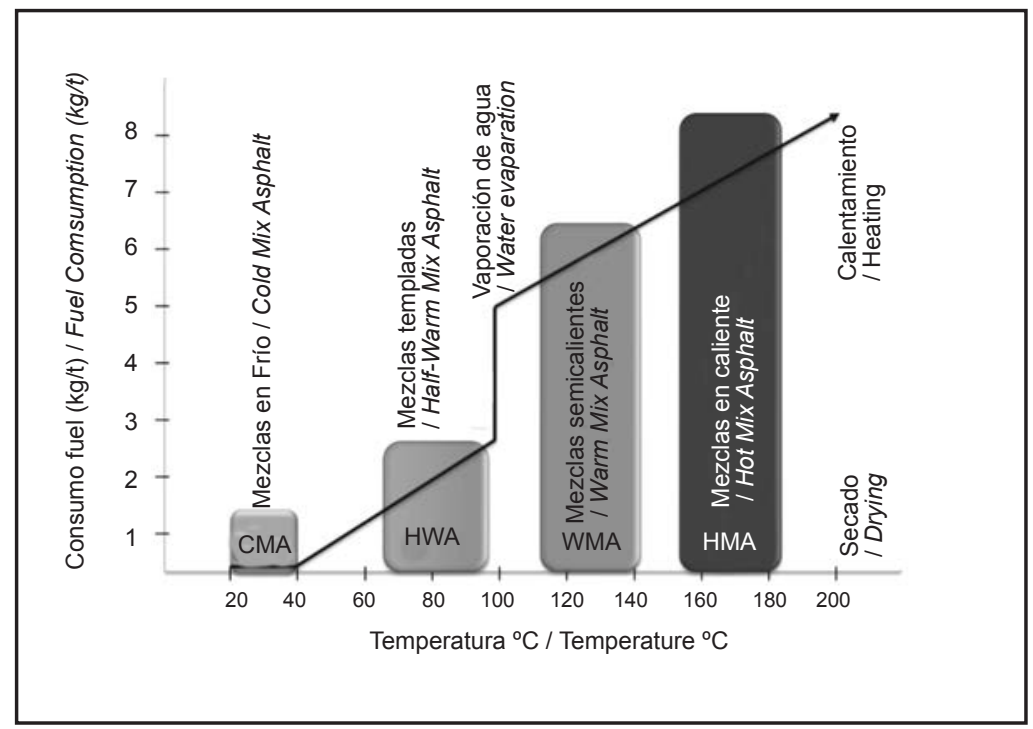

Figura 1. Clasificación aproximada de los diferentes tipos de mezclas por rango de temperatura y consumo de combustible. Figure 1. Classification of bituminous mixes, according to manufacturing temperature and fuel consumption.

parafinas (8). Por otra parte, investigaciones hechas con productos denominados tensoactivos han demostrado iguales prestaciones que los enunciados anteriormente (9). Todos ellos con un fundamento común, reducir la viscosidad del betún para poder fabricar, transportar y poner en obra mezclas bituminosas a temperaturas más bajas, sin perder su trabajabilidad ni características. Esto se traduce, tanto en la central como en la puesta en obra, en una apreciable reducción de emisiones gaseosas, de humos y de olores, así como en un proceso de extendido y compactación semejantes, incluso en condiciones climáticas poco favorables (4)

Actualmente las dos tecnologías principales que han empleado zeolita sintética en el diseño de mezclas son Asphamin $\AA$ desarrollada por Alemania (Eurovia) y Advera ${ }^{\circledR}$ por Estados Unidos. Ambos métodos permiten reducir la temperatura de extendido y compactación de las mezclas, sin que se produzca un detrimento en la trabajabilidad, ni en la calidad de la misma (7).

Las zeolitas son estructuras de silicatos con grandes espacios vacíos que permiten la presencia de cationes tales como Sodio $\left(\mathrm{Na}^{+}\right)$y Calcio $\left(\mathrm{Ca}^{2+}\right)$ y de moléculas de agua $\left(\mathrm{H}_{2} \mathrm{O}\right)$ (10). La mayoría de las zeolitas se caracterizan por su habilidad de perder y absorber agua sin dañar su estructura cristalina. Las zeolitas empleadas en estos procesos son aluminosilicatos de alkalimetales sintéticos, con la siguiente fórmula química $[1](6,11,12)$ : is similar to that of the other processes (9). However, all have the same basic purpose, namely, to reduce bitumen viscosity in order to be able to manufacture, transport, and spread mixes at lower temperatures with no detriment to theirproperties or workability. At the mix plant as well as at the worksite, this is reflected in a significant reduction of gas emissions, fumes, and odors as well as in ease of spreading and compaction, even in unfavorable climate conditions (4).

Currently, the two technologies that use synthetic zeo-

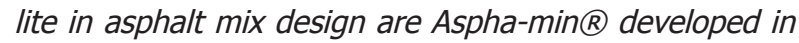
Germany (Eurovia) and Advera $\mathbb{R}$ in the United States. Both methods reduce the spreading and compaction temperatures of mixes without negatively affecting their workability and quality (7).

Zeolites are framework silicates with large empty spaces in their structures that allow the presence of cations, such as sodium $\left(\mathrm{Na}^{+}\right)$and calcium $\left(\mathrm{Ca}^{2+}\right)$, and molecules of water $\left(\mathrm{H}_{2} \mathrm{O}\right)(10)$. Most zeolites are characterized by their capacity to release or absorb water without any damage to their crystal structure. The zeolites used in asphalt mixes are synthetic aluminosilicates of alkali metals with the following chemical formula [1] $(6,11,12)$ :

$$
\mathrm{M}_{2} / \mathrm{zO} \cdot \mathrm{Al}_{2} \mathrm{O}_{3} \cdot \mathrm{x} \mathrm{SiO}_{2} \cdot \mathrm{y} \mathrm{H}_{2} \mathrm{O}
$$


Cuando se emplean en la fabricación de mezclas asfálticas, la zeolita, al añadirla a la mezcla y entrar en contacto con los materiales a temperaturas superiores a los $100^{\circ} \mathrm{C}$, libera el agua que contiene en su estructura y crea un efecto espumado en el betún, que provoca la reducción en la viscosidad del mismo y facilita la envuelta de los áridos a menores temperaturas que las empleadas normalmente en las mezclas tradicionales (10). El mezclado tiene lugar entre $130^{\circ} \mathrm{C}$ y $140^{\circ} \mathrm{C}$ y es importante que las partículas liberen el agua contenida en varios pasos y no de una sola vez. (7). El desprendimiento gradual del agua provee un período de 6 a 7 horas de trabajabilidad mejorada mientras que la temperatura se mantiene por encima de los $100{ }^{\circ} \mathrm{C}(212$ oF) $(6,11,12)$.

Las ventajas que presenta la aplicación de este proceso se resumen en una reducción artificial de la viscosidad del ligante, favorece la manejabilidad, permite el mezclado a temperaturas inferiores a las mezclas convencionales (20-30 ${ }^{\circ} \mathrm{C}$ menos), produce un ahorro de un $30 \%$ en la cantidad de combustible consumido por la planta $(10,13)$, reduce las emisiones de COV (compuestos órgano-volátiles), $\mathrm{SO}_{2}, \mathrm{NO}_{2}, \mathrm{CO}_{2}$, que se estiman en el rango $18-23 \%$ (14) y se obtienen mejoras en el nivel de compactación y en la resistencia a las deformaciones permanentes, con un reducido contenido de huecos (14).

En esta investigación se trazó como objetivo general evaluar la posibilidad de utilización de la zeolita natural en la fabricación de mezclas semicalientes, para lo cual en una etapa inicial se realiza un estudio comparativo entre mezclas con zeolita sintética y zeolita natural. Posteriormente se estudió la manera de incorporar la zeolita en las mezclas; en forma de arena o como filler, en distintas proporciones, dado que este material puede ser obtenido en diferentes fracciones. Luego de estos ensayos se comprobó que los resultados alcanzados cuando es añadida en forma de arena no eran significativamente superiores a los obtenidos como filler, por lo que se decidió centrar el estudio en la adición en forma de filler, ya que representa un ahorro del aditivo. Por último, se hicieron variar los porcentajes de zeolita en polvo y evaluar su influencia en las características de las mezclas, para obtener los porcentajes recomendados. Las pruebas utilizadas para esta investigación fueron los correspondientes al método Marshall (estabilidad, densidad, deformación y huecos mezclas y áridos), módulo de rigidez, así como la sensibilidad al agua de estas mezclas, ya que uno de los principales problemas reportados por la bibliografía acerca de los procesos de mezclas semicalientes que espuman el betún, es que puede ocurrir una incompleta evaporación del agua durante el mezclado y provocar retención de humedad causando deformaciones prematuras y separación de los materiales en los pavimentos (15).
In the manufacture of asphalt mixes, the zeolite is added at temperatures higher than $100{ }^{\circ} \mathrm{C}$. When the zeolite comes into contact with the other materials, the water in its structure is released. The bitumen then foams, which reduces its viscosity and also allows aggregate coating at lower temperatures than in hot mixes (10). The actual mixing process takes place at 1300-140 C. However, it is important for the zeolite particles to release their water content in various steps rather than all at once. This gradual release of water affords a six or seven-hour time period of optimal workability while the temperature remains above $100{ }^{\circ} \mathrm{C}(212$ of $)(6,11,12)$.

The advantages of this process include the following: (i) artificial reduction of binder viscosity; (ii) improved mix workability; (iii) mixing at lower temperatures (20-30 ${ }^{\circ} \mathrm{C}$ lower than in the case of hot mixes); (iv) 30\% cost savings in fuel consumption at the asphalt plant (10, 13); (v) $18-23 \%$ reduction in emissions from volatile organic compounds (VOCs, $\mathrm{SO}_{2}, \mathrm{NO}_{2}, \mathrm{CO}_{2}$ )(14); (vi) better compaction; ( $v$ ) enhanced resistance to permanent deformation with fewer air voids (14).

The main objective of this research was to evaluate the use of natural zeolite in the manufacture of warm asphalt mixes. The first stage of our study compared synthetic zeolite mixes to those using natural zeolite. The next step was to decide whether to add the zeolite to the mix in the form of sand or filler, and define the dosage since this material can be obtained in different fractions. The results showed that the mixes made with zeolite filler had a similar performance to those made with zeolite sand. For this reason, it was decided to add the zeolite as filler since this option had the advantage of saving on additives. Finally, in order to find the optimal job mix design, mixes were elaborated with different dosages of powdered zeolite in order to ascertain the impact of the dosage variation on the characteristics of the mix. To evaluate the mixes, we used the Marshall Method tests (stability, density, deformation, and air voids in mixes and aggregate), and also assessed their stiffness modulus as well as their moisture susceptibility. This was important since one of the problems cited in the research on warm mixes with bitumen foam is that an incomplete evaporation of water can occur during the mixing process. This produces moisture retention, which can lead to premature pavement deformations and aggregate stripping (15). 


\section{METODOLOGÍA}

\subsection{Materiales}

La tipología de mezcla utilizada durante todo el estudio fue una AC 16 SURF 50/70 S (16), y para su fabricación se emplearon tres fracciones de áridos y un filler de aportación, ambos de origen calizo. En la Tabla 1 se presentan las propiedades de estos materiales.

\section{METHODOLOGY}

\subsection{Materials}

For this study, we used an AC 16 SURF 50/70 S mix (16), manufactured with limestone filler and three fractions of limestone aggregate. Table 1 shows the properties of these materials.

Tabla 1 / Table 1

Propiedades de los áridos.

Aggregate properties.

\begin{tabular}{|c|c|c|c|c|c|c|c|c|c|}
\hline \multirow{2}{*}{$\begin{array}{c}\text { Fracción I } \\
\text { Fraction } \\
(\mathbf{m m})\end{array}$} & \multicolumn{3}{|c|}{$\begin{array}{l}\text { Peso específico / Weight } \\
(\mathrm{g} / \mathrm{cm} 3)\end{array}$} & \multirow{2}{*}{$\begin{array}{c}\text { Absorción / } \\
\text { Absorption (\%) }\end{array}$} & \multirow{2}{*}{$\begin{array}{l}\text { Índice de } \\
\text { Lajas / } \\
\text { Flakiness in } \\
\text { dex (\%) }\end{array}$} & \multirow{2}{*}{$\begin{array}{l}\text { Coeficiente } \\
\text { los } \\
\text { Ángeles I } \\
\text { Los } \\
\text { Angeles } \\
\text { coefficient } \\
(\%)\end{array}$} & \multirow{2}{*}{$\begin{array}{c}\text { Caras de } \\
\text { fractura I } \\
\text { Fractured } \\
\text { face (\%) }\end{array}$} & \multirow{2}{*}{$\begin{array}{c}\text { Equivalente } \\
\text { de Arena / } \\
\text { Sand } \\
\text { equivalent } \\
\text { (\%) }\end{array}$} & \multirow{2}{*}{$\begin{array}{c}\text { Densidad en } \\
\text { queroseno / } \\
\text { Kerosene } \\
\text { density }(\mathrm{g} / \mathrm{cm} 3)\end{array}$} \\
\hline & DAAS & DS.S.S & DREAL & & & & & & \\
\hline $12-18$ & 2.77 & 2.78 & 2.81 & 0.51 & 3 & \multirow{2}{*}{20} & 90 & & \\
\hline $6-12$ & 2.78 & 2.80 & 2.83 & 0.58 & 2 & & 77 & & \\
\hline $0-5$ & 2.73 & 2.75 & 2.77 & 0.51 & & & & 72 & \\
\hline filler & & & & & & & & & 0.61 \\
\hline
\end{tabular}

El ligante empleado en la fabricación de todas las mezclas fue un betún de penetración 50/70, adicionado en porcentaje del $4,3 \%$ sobre el peso de la mezcla (previamente obtenido mediante el estudio de la fórmula de trabajo). En la Tabla 2 se muestran sus características.
The binder used in the mixes was bitumen penetration grade $50 / 70$ at a dosage of $4.3 \%$ of the mix weight (percentage previously obtained in our specification of the optimal mix formula). Table 2 shows the characteristics of this bitumen.

Tabla 2 / Table 2

Propiedades del betún empleado. Bitumen characteristics.

\begin{tabular}{|c|c|}
\hline \multicolumn{2}{|c|}{ Propiedades del betún 50/70 / Bitumen 50/70 characteristics } \\
\hline Penetración / Penetration $\left(25^{\circ} \mathrm{C} 100 \mathrm{~g} / 5 \mathrm{~s}\right) 1 / 10 \mathrm{~mm}$ & 68 \\
\hline Punto de Reblandecimiento / Softening point $\left({ }^{\circ} \mathrm{C}\right)$ & 48.1 \\
\hline Punto de Fragilidad FRAAS / FRAAS breaking point $\left({ }^{\circ} \mathrm{C}\right)$ & -12 \\
\hline Punto de Inflamación / Flash point COC $\left({ }^{\circ} \mathrm{C}\right)$ & 301 \\
\hline Densidad / Density $25^{\circ} \mathrm{C}(\mathrm{kg} / \mathrm{l})$ & 1.037 \\
\hline Viscosidad / Viscosity $135^{\circ} \mathrm{C}(\mathrm{cSt})$ & 486.3 \\
\hline
\end{tabular}

Como aditivos se emplearon una zeolita sintética (Asphamin ${ }$, Eurovía) y una zeolita natural de la cantera de Tasajera en la provincia Villa Clara en Cuba.

La zeolita sintética es un aluminosilicato de sodio que contiene alrededor de un $20 \%$ de agua de cristalización, la cual se desprende a temperaturas superiores a los $100^{\circ} \mathrm{C}$. Se comercializa en forma de polvo blanco muy fino y en forma granular, y normalmente es adicionada en cantidades del entorno de $0,3 \%$ sobre el peso de la mezcla $(6,10-12,17)$, justo antes o al mismo tiempo que es añadido el betún. La liberación del agua crea

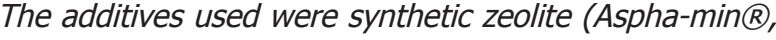
Eurovía) and natural zeolite obtained from the Tasajera quarry in the province of Villa Clara, Cuba.

The synthetic zeolite is an aluminosilicate containing roughly 20\% water of crystallization, which is released at temperatures over $100^{\circ} \mathrm{C}$. It is sold as very fine white powder or in granular form. It is generally added just before or at the same time as the bitumen, and its dosage is approximately $0.3 \%$ of the mix weight $(6,10$ $12,17)$. The release of the water causes the bitumen to foam, which increases the volume of the bitumen and 
un efecto de espumado que produce un aumento en el volumen del betún, reduciendo su viscosidad. Así, resulta extremadamente importante que la adición de la zeolita no prolongue el proceso de mezclado, de forma que su adición no influya en el funcionamiento de la planta (7).

La zeolita natural cubana es un mineral abundante en el país, estando distribuida en varias provincias, siendo considerada como una de las mayores reservas mundiales de dicho mineral. Tienen un contenido zeolítico superior al $50 \%$, fundamentalmente de clinoptilolita y mordenita (18). Este mineral es un producto altamente cotizado a nivel mundial, del cual se conocen grandes beneficios en un sin número de aplicaciones industriales, a merced de sus propiedades físico-químicas. La agricultura, la construcción y la medicina son algunos de los sectores donde se ha probado su utilidad; además es muy eficaz en el tratamiento de aguas residuales y potabilizadoras (19). Tienen la capacidad de almacenar grandes cantidades de agua en sus moléculas, característica que hace posible su aplicación en las mezclas asfálticas para producir el espumado del asfalto y reducir su viscosidad.

Las propiedades químicas y físicas que caracterizan a las zeolitas naturales son $(20,21)$ :

- Su capacidad de intercambio iónico.

- La deshidratación-hidratación como procesos físicos.

- Adsorción.

Todas estas propiedades están asociadas a su estructura, armazón molecular y a su composición catiónica, que en el caso de las zeolitas naturales suele ser [2]: reduces its viscosity. The addition of the zeolite should not prolong the mixing process or influence the operation of the asphalt mix plant in any way (7).

Natural zeolite is found in many provinces in Cuba, a country that has one of the largest reserves of this mineral in the world. The zeolite content of the material found there is higher than 50\%, and is mainly composed of clinoptilolite and mordenite (18). Zeolite is a highly valued mineral since it has a countless number of industrial applications, thanks to its physico-chemical properties. Agriculture, construction, and medicine are only a few of the sectors in which the usefulness of this mineral has been amply demonstrated. Moreover, it is very effective in both drinking water and wastewater treatment plants (19). This mineral has the capacity of storing large quantities of water in its molecules, which means that it can be used in asphalt mixes to make the asphalt foam, and thus reduceitsviscosity.

The chemical and physical properties of natural zeolite are the following $(20,21)$ :

- Capacity for ion exchange.

- Dehydration-hydration as physical processes.

- Adsorption.

All of the above properties are associated with the structure, molecular framework, and cationic compositions of zeolite, which in the case of natural zeolite is usually the following [2]:

$$
\mathrm{M}_{\mathrm{m} \_z} \mathrm{AL}_{\mathrm{m}} \mathrm{Si}_{\mathrm{n}} \mathrm{O}_{2}(\mathrm{~m}+\mathrm{n}) * \mathrm{qH}_{2} \mathrm{O}
$$

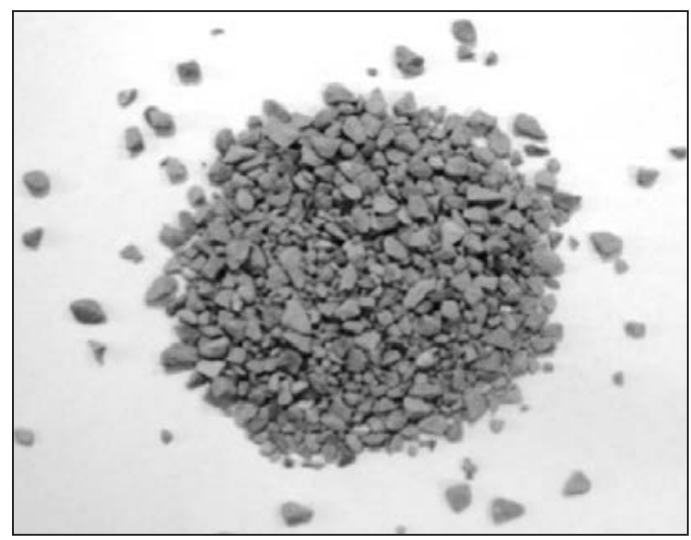

Figura 2. Zeolita natural en forma de grano. Figure 2. Natural zeolite in granular form. 
La zeolita natural empleada en este trabajo tiene un tamaño máximo de $4 \mathrm{~mm}$ (Figura 2), por lo que se le realizaron los ensayos relativos a una arena: densidad aparente y densidad del filler en queroseno, absorción, humedad, equivalente de arena y granulometría. En la Tabla 3 y Figura 3 se muestran sus características, como arena y como filler. La Tabla 3 contiene algunas características de la zeolita sintética.
The natural zeolite used in this study has a maximum particle-size of $4 \mathrm{~mm}$ (see Figure 2). For this reason, the tests performed were the same as those for sand (i.e. apparent density, density of the filler in kerosene, absorption, moisture, sand equivalent, and particle size). Table 3 and Figure 3 show the characteristics of zeolite sand and filler, respectively. Table 3 also shows some of the characteristics of synthetic zeolite.

Tabla 3 / Table 3

Propiedades de las zeolitas.

Zeolite properties.

\begin{tabular}{|c|c|c|c|c|c|}
\hline & $\begin{array}{l}\text { Humedad I } \\
\text { Moisture (\%) }\end{array}$ & $\begin{array}{c}\text { Absorción I } \\
\text { Absorption (\%) }\end{array}$ & $\begin{array}{l}\text { Densidad aparente I } \\
\text { Apparent density } \\
\left(\mathrm{g} / \mathrm{cm}^{3}\right)\end{array}$ & $\begin{array}{c}\text { Densidad en } \\
\text { queroseno / Density } \\
\text { in kerosene }\left(\mathrm{g} / \mathrm{cm}^{3}\right)\end{array}$ & $\begin{array}{l}\text { Equivalente de Arena I } \\
\text { Sand equivalent (\%) }\end{array}$ \\
\hline $\begin{array}{l}\text { Zeo Sintetica / } \\
\text { Synthetic zeolite }\end{array}$ & & Hasta / Up to 21 & 2.0 & $\begin{array}{l}\text { No procede I } \\
\text { Not relevant }\end{array}$ & $\begin{array}{l}\text { No procede I } \\
\text { Not relevant }\end{array}$ \\
\hline $\begin{array}{l}\text { Zeo Natural filler I } \\
\text { Natural zeolite filler }\end{array}$ & \multirow{2}{*}{14.3} & 23.7 & 2.34 & 2.24 & 64 \\
\hline $\begin{array}{l}\text { Zeo Natural arena / } \\
\text { Natural zeolite sand }\end{array}$ & & 16.5 & 2.35 & $\begin{array}{l}\text { No aplicable / } \\
\text { Not applicable }\end{array}$ & $\begin{array}{l}\text { No aplicable / } \\
\text { Not applicable }\end{array}$ \\
\hline
\end{tabular}

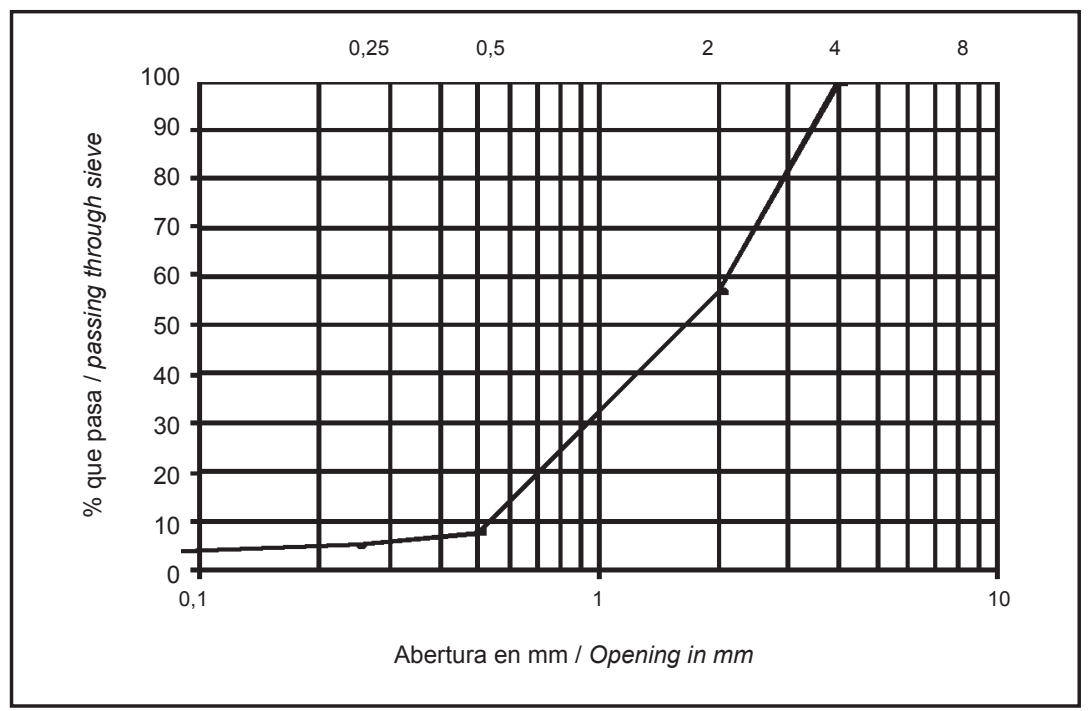

Figura 3. Granulometría de la zeolita natural cubana.

Figure 3. Grain size of Cuban natural zeolite.

Además, se sometió al ensayo de microscopía electrónica utilizando un microscopio de barrido (scanning microscope) JEOL JSM-6300, que permitió conocer la composición química de la zeolita (Figura 4 (b) y (c)), tanto de la muestra en general como en algunos espectros analizados. Una imagen ampliada de la estructura de la zeolita y los puntos examinados viene recogida en la Figura 4 (a), donde puede observarse una muestra bastante homogénea, dado que casi todas las partículas presentan el mismo brillo.

Con el propósito de profundizar en las características de este material, se realizó un análisis de la porosidad de la zeolita, mediante el empleo de la isoterma de adsorción de nitrógeno $\left(\mathrm{N}_{2}\right)$ a $77^{\circ} \mathrm{K}$ (Figura $5(\mathrm{a})$ ). El equipo utilizado fue un AUTOSOR 1 (Quanta Chrome), que procesa la
Furthermore, the zeolite was analyzed with an electronic microscope, namely a JEOL JSM-6300 scanning microscope, which provided the chemical composition of the zeolite of the sample in general as well in some of the spectra (Figures $4 b$ and $4 c$ ). Figure $4 a$ shows an enlarged image of the zeolite structure and the points examined. As can be observed, the sample is fairly homogeneous, given that all particles have the same brightness.

To further study the characteristics of this material, the pore-size distribution of the zeolite was calculated, based on the nitrogen $\left(\mathrm{N}_{2}\right)$ adsorption isotherm at $77{ }^{\circ} \mathrm{K}$ (Figure 5a). The instrument used wasAUTOSORB 1 (Quanta Chrome), which processed the information 
(a)
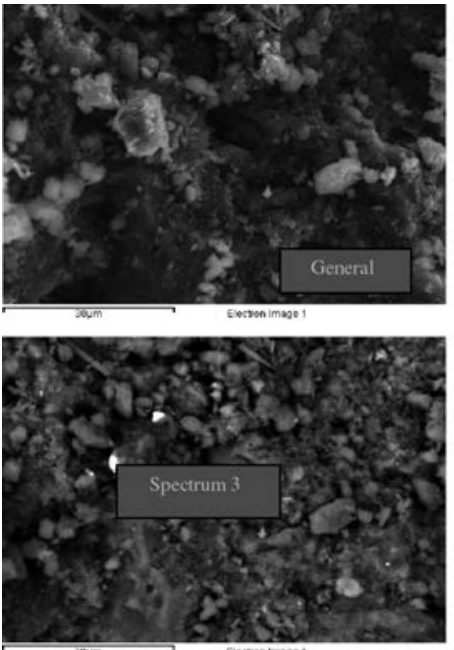

(b)

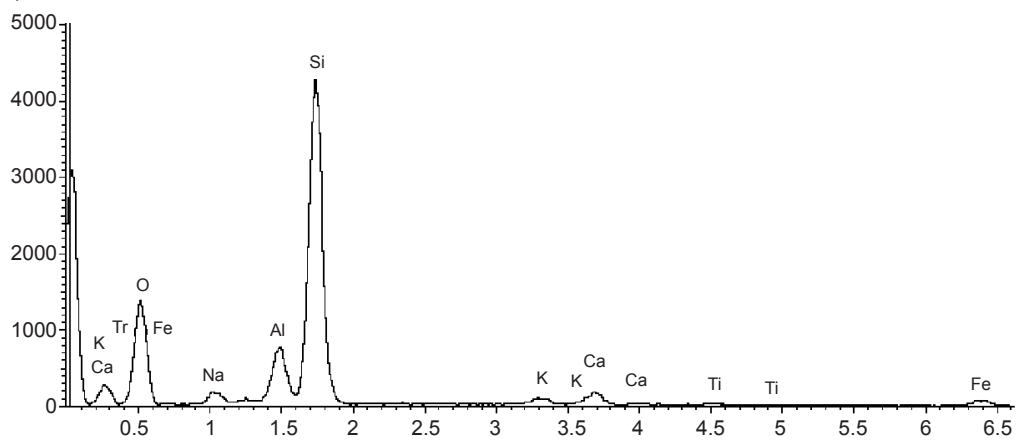

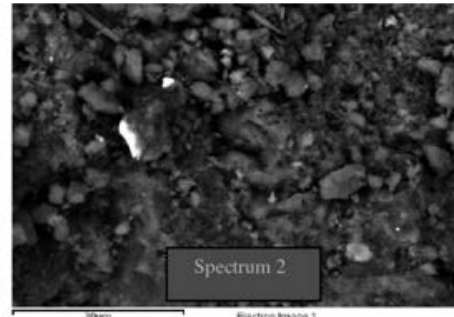

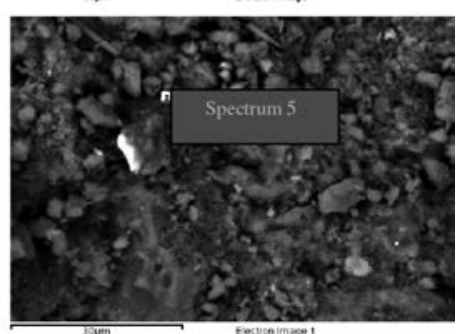

(c)

\begin{tabular}{|c|c|c|}
\hline $\begin{array}{c}\text { Element / } \\
\text { Element }\end{array}$ & $\begin{array}{c}\text { Peso / } \\
\text { Weight \% }\end{array}$ & $\begin{array}{c}\text { Atómico / } \\
\text { Atomic \% }\end{array}$ \\
\hline $\mathrm{O}$ & 43.96 & 58.99 \\
\hline $\mathrm{Na}$ & 1.98 & 1.85 \\
\hline $\mathrm{Al}$ & 6.81 & 5.42 \\
\hline $\mathrm{Si}$ & 39.44 & 30.15 \\
\hline $\mathrm{K}$ & 2.02 & 1.11 \\
\hline $\mathrm{Ca}$ & 1.69 & 0.90 \\
\hline $\mathrm{Fe}$ & 4.11 & 1.58 \\
\hline $\begin{array}{c}\text { Totales / } \\
\text { Totals }\end{array}$ & 100.00 & \\
\hline \multicolumn{2}{|c}{} \\
\hline
\end{tabular}

Figura 4. Imagen microscópica general y de 3 espectros de la zeolita natural cubana (a), distribución de los componentes (muestra general) (b) y composición química (muestra general) (c).

Figure 4. (a) General microscopic image and three spectra of Cuban natural zeolite; (b) distribution of components (general sample); (c) chemical composition (general sample).

información mediante el software AS 1 win versión 2.01 y los métodos DR (Dubinin-Radushkevich) para determinar el volumen de poros, el BET (Brunauer-Emmett-Teller) para el área superficial y el NLDFT (Non-Local Density Functional Theory) para la distribución de tamaño de poros. with the software application AS1Win version 2.01. Also used were the Dubinin-Radushkevich (DR) method to determine pore volume, the Brunauer, Emmett and Teller (BET) method for the surface area, and the Non-Local Density Functional Theory (NLFDT) for the pore-size distribution. (a)

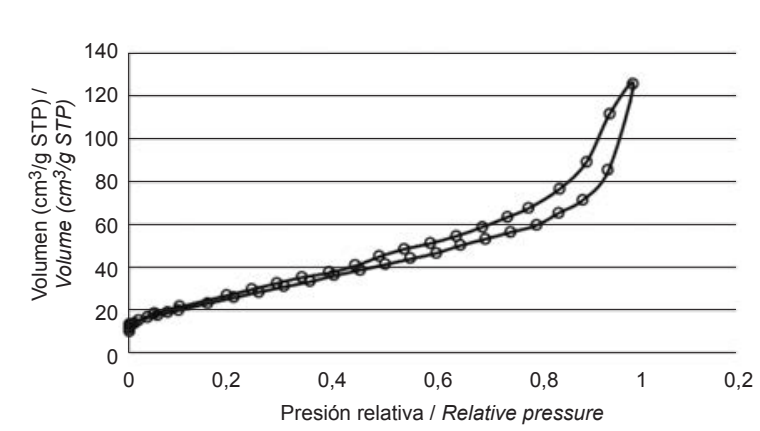

(b) Distribución de tamaño de poros / Pore-size distribution

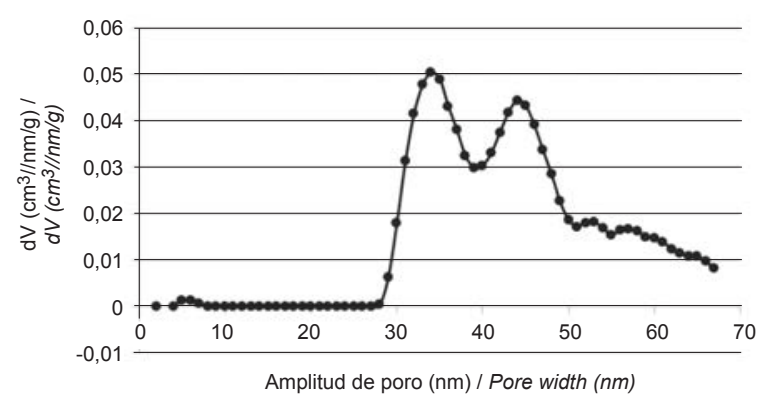

Figura 5. Isoterma de adsorción de Nitrógeno (a), distribución de tamaño de poros (b). Figure 5 (a) Nitrogen adsorption isotherm; (b) pore-size distribution. 
Como resultado de este ensayo se obtuvo que la zeolita natural empleada no tiene una microporosidad homogénea, pues presenta diferentes tamaños de poros, llegando a alcanzar un máximo de 1,75 nanómetros, lo que se considera un tamaño grande, ya que los mesoporos se identifican cuando el tamaño es mayor de 2 nanómetros (Figura 5 (b)). El volumen de microporos es de 0,25 $\mathrm{cm}^{3} / \mathrm{g}$, con un tamaño medio de 0,6 nanómetros y una superficie específica de $77,478 \mathrm{~m}^{2} / \mathrm{g}$.

También fue evaluada la variación del contenido de humedad de la zeolita en el tiempo, a temperatura constante, para lo cual se midieron las pérdidas de peso de muestras mantenidas en estufa a temperaturas de 110,130 y 150 ${ }^{\circ} \mathrm{C}$; lo que ofreció información acerca de la influencia de la temperatura durante el proceso de mezclado. Los resultados de dicho análisis se muestran en la Figura 6.
The results of this test showed that the natural zeolite did not have a homogeneous microporosity. Its maximum pore size was 1.75 nanometers, which is fairly large, since pores with a size of 2 nanometers are defined asmesopores(Figure $5 b$ ). The micropores of the zeolite were found to have a volume of $0.25 \mathrm{~cm}^{3} / \mathrm{g}$, with a mean size of 0.6 nanometers and a specific surface of $77.478 \mathrm{~m}^{2} / \mathrm{g}$.

Also evaluated was the variation in the moisture content of the zeolite at a constant temperature. For this purpose, weight losses in oven-cured samples were measured at temperatures of 110,130 , and $150{ }^{\circ} \mathrm{C}$. This provided information regarding the impact of the temperature on the mixing process. The results of this analysis are shown in Figure 6.

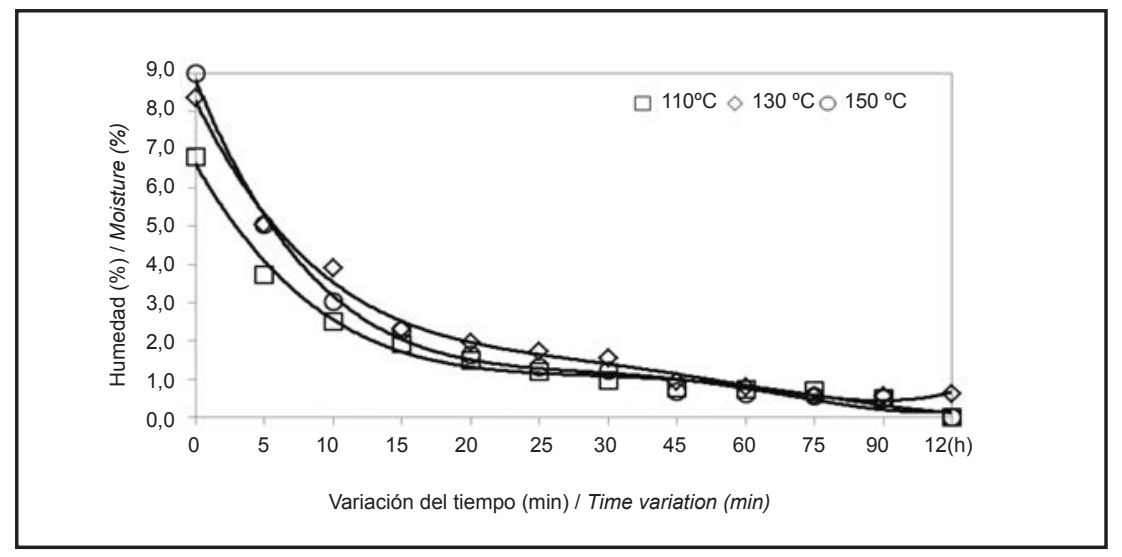

Figura 6. Pérdida de humedad del filler de zeolita en el tiempo a temperatura constante. Figure 6. Progressive loss of moisture of the zeolite filler at a constant temperature.

Se observa que en los primeros cinco minutos la zeolita natural pierde aproximadamente el $50 \%$ de la humedad que contenía al inicio del ensayo, y es independiente de la temperatura, en el rango ensayado. Parece suficiente elevar la temperatura hasta $110^{\circ} \mathrm{C}$ para producir el efecto de pérdida de humedad en la zeolita.

Para valorar la capacidad de adsorción de la zeolita natural, a diferentes tamaños de granos, se midió el incremento de la humedad en ambiente de laboratorio, de la zeolita en forma de filler y de arena, utilizando cantidades similares de material e iguales contenidos de humedad inicial. Primero fueron secadas en estufa ambas muestras de material y luego se midió el cambio de peso en el tiempo, a temperatura ambiente. Se observa (Figura 7) que el filler incrementa su humedad con mayor rapidez que la arena, notándose que a las 5 horas de medición ya había alcanzado la humedad inicial, lo que para el caso de la arena no sucedió ni siquiera a las 24 horas posteriores al ensayo. Este hecho puede explicarse debido a la mayor
As can be observed, in the first five minutes, the natural zeolite lost approximately $50 \%$ of its initial moisture content. The loss was also found to be independent of the temperature level with in the temperature range of the experiment. The temperature only had to be raised to $110^{\circ} \mathrm{C}$ for the zeolite to lose moisture.

To assess the adsorption capacity of natural zeolite of different grain sizes, we measured the moisture increase of the zeolite filler and zeolite sand in laboratory conditions. For this purpose, we tested similar amounts of both types of material with the same initial moisture content. The samples were first oven-dried, and their change in weight at ambient temperature measured. According to Figure 7, the zeolite filler showed a greater increase in moisture than the sand. In fact, five hours after the first measurement, the filler had regained its initial moisture level. In contrast, this was not thecase for the sand even 24 hours after the test. This can be explained by the larger specific surface of the filler, and 
superficie específica del filler, y por tanto, mayor capacidad de adsorción; así podemos decir que la zeolita en tamaños menores a 0,063 $\mathrm{mm}$ posiblemente sea un aditivo más efectivo que en tamaños mayores, para reducir la temperatura de la mezcla. consequently, its greater adsorption capacity. Thus, to reduce the temperature of the mix, zeolite with a grain size smaller than $0.063 \mathrm{~mm}$ might be more effective than zeolite of a larger grain size.

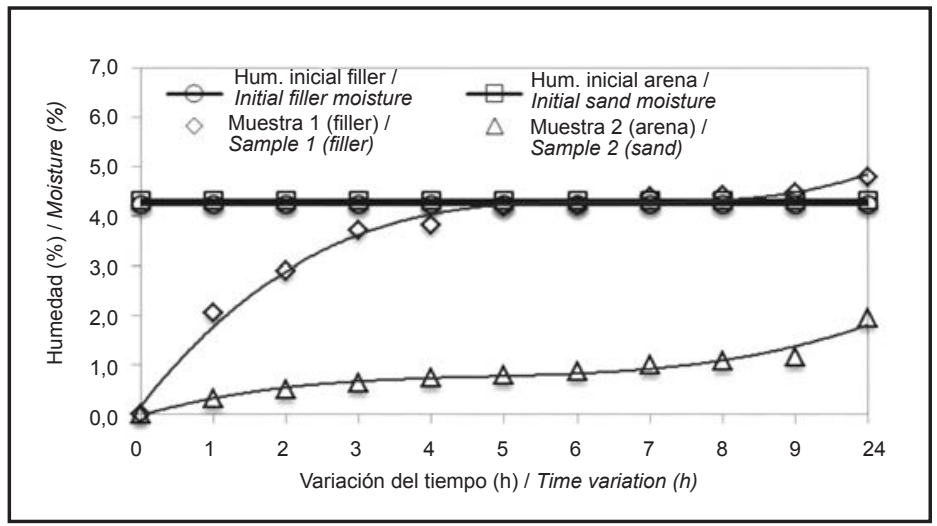

Figura 7. Incremento de la humedad zeolita en el tiempo. Figure 7. Moisture increase in the zeolite over time.

\subsection{Plan de ensayos}

Para la realización de este estudio, las mezclas a ensayar son:

- Mezcla patrón: AC16 SURF 50/70 S.

- Mezcla patrón a la que se adicionan zeolitas naturales en diferentes porcentajes tanto en la fracción arena como filler, lo que suponen un total de 8 mezclas.

- Mezcla patrón a la que se adiciona zeolita sintética en un $0,3 \%$ sobre el peso de la mezcla.

En la Tabla 4 se relacionan los diferentes ensayos realizados a las mezclas estudiadas y los porcentajes añadidos de zeolitas como filler y como arena. En todos los casos se fabricaron 3 probetas por cada mezcla. La mezcla patrón se trabajó con una temperatura de mezclado entre $150-160{ }^{\circ} \mathrm{C}$ y de compactación de $145-155{ }^{\circ} \mathrm{C}$, por su parte las mezclas con adición de zeolitas se trabajaron con temperaturas de mezclado de $130-140{ }^{\circ} \mathrm{C}$ y de compactación de $120-125^{\circ} \mathrm{C}$ (Tabla 5). El betún fue calentado para todas las mezclas entre $150-160^{\circ} \mathrm{C}$. El procedimiento de diseño seguido fue el mismo en todos los casos y de forma idéntica que para las mezclas convencionales, con la particularidad que el aditivo se mezcla justo antes o en el momento en que se añade el betún.

\subsection{Experimental design}

The mixes analyzed in this study were the following:

- Reference mix: AC16 SURF 50/70 S.

- Reference mix with different dosages of natural zeolite added in the sand fraction as well as the filler (a total of eight mixes).

- Reference mix with synthetic zeolite at a dosage of $0.3 \%$ of the mix weight.

Table 4 shows the different tests performed on the mixes as well as the dosages of zeolite filler and zeolite sand added to the mix. In all cases, three test specimens were manufactured for each mix. The reference mix was elaborated at a mixing temperature of $150-160{ }^{\circ} \mathrm{C}$ and a compaction temperature of $145-155^{\circ} \mathrm{C}$. The zeolite mixes were manufactured at a mixing temperature of 130-140 ${ }^{\circ} \mathrm{C}$ and a compaction temperature of $120-125^{\circ} \mathrm{C}$ (Table 5). The bitumen was heated for all the mixes at 150-160 ${ }^{\circ} \mathrm{C}$. The mix design procedure was the same in all cases and identical to that of conventional mixes with the difference that the additive wasput into the mix just before or at the same time that the bitumen was added. 
Tabla 4 / Table 4

Ensayos realizados a las diferentes mezclas estudiadas y porcentajes añadidos de zeolitas como filler o como arena. Tests performed on the mixes with zeolite added as filler and sand.

\begin{tabular}{|c|c|c|c|c|c|c|c|c|}
\hline \multirow[b]{2}{*}{ Mezcla / Mix } & \multirow[b]{2}{*}{$\begin{array}{c}\text { Adición / } \\
\text { Dosage (\%) }\end{array}$} & \multicolumn{7}{|c|}{ Ensayos / Tests } \\
\hline & & $\begin{array}{c}\text { Densidad / } \\
\text { Density } \\
\text { (NLT-168) }\end{array}$ & $\begin{array}{l}\text { Huecos } \\
\text { Mezcla / } \\
\text { Air voids } \\
\text { Mix } \\
\text { (NLT-168) }\end{array}$ & $\begin{array}{l}\text { Huecos } \\
\text { Áridos / } \\
\text { Air voids } \\
\text { Aggregate } \\
\text { (NLT-168) }\end{array}$ & $\begin{array}{c}\text { Estabilidad / } \\
\text { Stability } \\
\text { (NLT-159) }\end{array}$ & $\begin{array}{l}\text { Deformación / } \\
\text { Deformation } \\
\text { (NLT 159) }\end{array}$ & $\begin{array}{c}\text { Sensibilidad } \\
\text { al agua / } \\
\text { Moisture } \\
\text { sensitivity } \\
\text { (UNE-EN } \\
\text { 12697-12) }\end{array}$ & $\begin{array}{l}\text { Módulo de rigidez / } \\
\text { Stiffnessmodulus } \\
\text { (UNE-EN 12697-26, } \\
\text { anexo / annex C) }\end{array}$ \\
\hline $\begin{array}{c}\text { Patrón / } \\
\text { Reference }\end{array}$ & 0 & $x$ & $x$ & $x$ & $x$ & $x$ & $x$ & $x$ \\
\hline $\begin{array}{c}\text { Zeolita Sintética } \\
\text { / Synthetic } \\
\text { zeolite }\end{array}$ & 0.3 & $x$ & $x$ & $x$ & $x$ & $x$ & & \\
\hline \multirow{3}{*}{$\begin{array}{l}\text { Zeolita Natural } \\
\text { / Natural zeolite } \\
\text { (filler) }\end{array}$} & 0.3 & $x$ & $x$ & $x$ & $x$ & $x$ & $x$ & $x$ \\
\hline & 0.6 & $x$ & $x$ & $x$ & $x$ & $x$ & $x$ & \\
\hline & 1.0 & $x$ & $x$ & $x$ & $x$ & $x$ & $x$ & $x$ \\
\hline \multirow{5}{*}{$\begin{array}{l}\text { Zeolita natural } \\
\text { (arena) / } \\
\text { Natural zeolite } \\
\text { (sand) }\end{array}$} & $1.0^{*}$ & $x$ & $x$ & $x$ & $x$ & $x$ & & $x$ \\
\hline & $2.0^{\star *}$ & $x$ & $x$ & $x$ & $x$ & $x$ & & \\
\hline & $6.0^{* *}$ & $x$ & $x$ & $x$ & $x$ & $x$ & & \\
\hline & $10.0^{* *}$ & $x$ & $x$ & $x$ & $x$ & $x$ & & $x$ \\
\hline & $20.0^{* *}$ & $x$ & $x$ & $x$ & $x$ & $x$ & & \\
\hline
\end{tabular}

*Este $1 \%$ de arena está compuesto por un 0,7\% de zeolita de tamaño 0,063-0,50 mm y un 0,3\% de filler. / *This $1 \%$ sand is composed of 0.7\% zeolite with a 0.063-0.50 $\mathrm{mm}$ grain size and $0.3 \%$ filler.

**Compuesto por todos los tamaños del grano de la zeolita (0-4 mm) y un contenido de $0,3 \%$ de filler. / **Composed of all the zeolite grain sizes (0-4 mm) and $0.3 \%$ filler.

Tabla 5 / Table 5

Condiciones de diseño de las mezclas fabricadas.

Mix design conditions.

\begin{tabular}{|c|c|c|}
\hline & \multicolumn{2}{|c|}{ Tipo de mezcla / Mix type } \\
\hline Parámetros / Parameters & Mezcla Patrón / Reference mix & Mezclas con zeolitas / Zeolite mixes \\
\hline $\mathrm{T}^{\circ}$ de los áridos / Aggregate temp $\left({ }^{\circ} \mathrm{C}\right)$ & $150-160$ & $130-140$ \\
\hline $\mathrm{T}^{\circ}$ del betún / Bitumen temp $\left({ }^{\circ} \mathrm{C}\right)$ & $150-160$ & $150-160$ \\
\hline $\mathrm{T}^{\circ}$ de mezclado / Mix temp $\left({ }^{\circ} \mathrm{C}\right)$ & $150-160$ & $130-140$ \\
\hline $\mathrm{T}^{\circ}$ de compactación / Compaction temp $\left({ }^{\circ} \mathrm{C}\right)$ & $145-155$ & $120-125$ \\
\hline Tiempo de mezclado / Mix time (min) & 3 & 3 \\
\hline
\end{tabular}

\subsubsection{Comparación de mezclas fabricadas con zeolita sintética y natural}

Con el propósito de valorar si la zeolita natural produce el mismo efecto en las mezclas asfálticas que una zeolita sintética, se prepararon tres mezclas, una convencional como patrón de referencia, una con zeolita sintética y otra con zeolita natural. Los aditivos se añadieron en forma de filler en un 0,3\% de la mezcla, como plantea la bibliografía $(6,11,12,17)$. En la Tabla 6 se presentan los pesos específicos de los áridos combinados de las tres mezclas ensayas y en la Figura 8, se muestra el huso granulométrico empleado. Se realizaron los ensayos de estabilidad Marshall, deformación, densidad y porcentajes de huecos mezcla y áridos.

\subsubsection{Comparison of synthetic zeolite and natural zeolite mixes}

To evaluate whether natural zeolite produced the same effect as synthetic zeolite, we prepared three mixes: (i) a conventional mix, which acted as the reference mix; (ii) a mix with synthetic zeolite; (iii) a mix with natural zeolite. The zeolite was added as filler at a dosage of $0.3 \%$ of the mix weight $(6,11,12,17)$. Table 6 shows the specific weights of the combined aggregates of the three mixes, and Figure 8 lists their grain size. The mixes were tested for Marshall stability, deformation, density, and air voids in the aggregate as well as in the mix itself. 
Tabla 6 / Table 6

Peso específico de los áridos combinados para las diferentes mezclas ensayadas. Specific weight of the combined aggregates in the mixes.

\begin{tabular}{|c|c|c|c|}
\hline Mezcla / Mix & Patrón / Reference & $\begin{array}{l}\mathbf{0 . 3 \%} \text { Zeolita sintética / } \\
\text { Synthetic zeolite (filler) }\end{array}$ & $\begin{array}{l}\mathbf{0 . 3 \%} \text { Zeolita natural / } \\
\text { Natural zeolite (filler) }\end{array}$ \\
\hline PE combinado / Combined specific weight & 2.83 & 2.80 & 2.88 \\
\hline
\end{tabular}

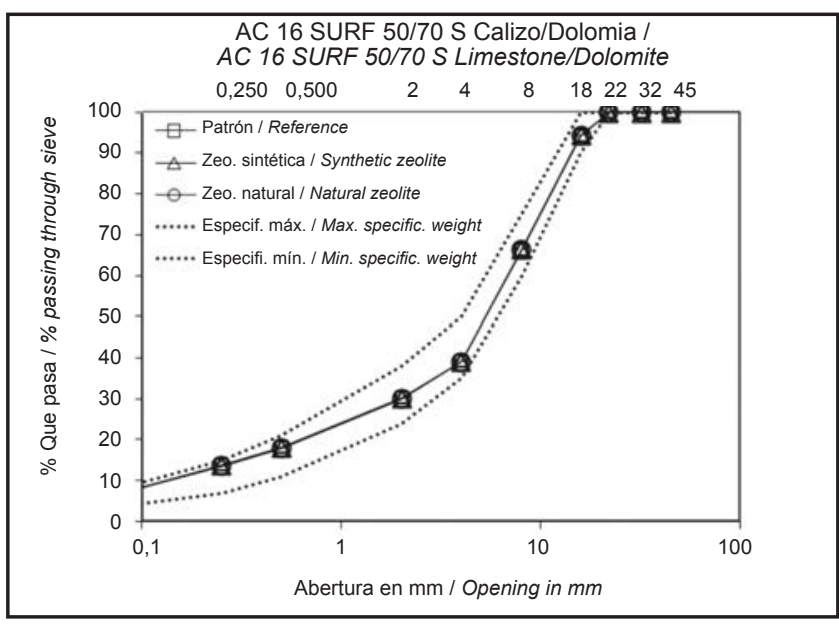

Figura 8. Granulometría de las mezclas. Figure 8. Grain size of the mixes.

\subsubsection{Adición de zeolita como arena}

Otra parte de la investigación se centró en el estudio del tamaño de granos más adecuado para la adición de la zeolita natural, ya que este material puede obtenerse en diferentes tamaños. Así, se trabajó sobre dos objetivos. El primero de ellos:

a) Analizar la influencia del incremento de zeolita en forma de arena (0-4 mm), añadiendo cuatro porcentajes diferentes $(2 \%, 6 \%, 10 \%$ y $20 \%)$. Las pruebas se someterían al ensayo de estabilidad Marshall, deformación, densidad, porcentaje de huecos en mezcla y en áridos.

A pesar de emplear en todos los casos la misma granulometría, la incorporación de un material granular en diferentes proporciones produce evidentemente algunas variaciones en la graduación de la mezcla (Figura 9). La Tabla 7 muestra los porcentajes de las diferentes fracciones de áridos empleados y de arena de zeolita natural en función de los distintos tipos de mezclas preparados. También tuvo variación el peso específico de los áridos combinados ( $\mathrm{PE}_{\mathrm{comb}}$ ) (Tabla 8).

\subsubsection{Dosage of zeolite sand}

This research also focused on the selection of the most suitable grain size for natural zeolite dosage since this material comes in different sizes. Our study thus had two objectives, the first of which was the following:

a) To compare asphalt mixes with dosagesof zeolite sand $(0-4 \mathrm{~mm})$ at $2 \%, 6 \%, 10 \%$, and $20 \%$. The mixes were analyzed with the Marshall stability test, deformation, density, and air voids in the mix and the aggregate.

Despite the fact that in all cases, the same grain size was used, the incorporation of different percentages of granular material evidently produces variations in mix gradation (Figure 9). Table 7 shows the percentages of the aggregate fractions used and of the natural zeolite sand, according to mix type. The specific weight of the combined aggregates (SW comb) also varied (see Table 8). 


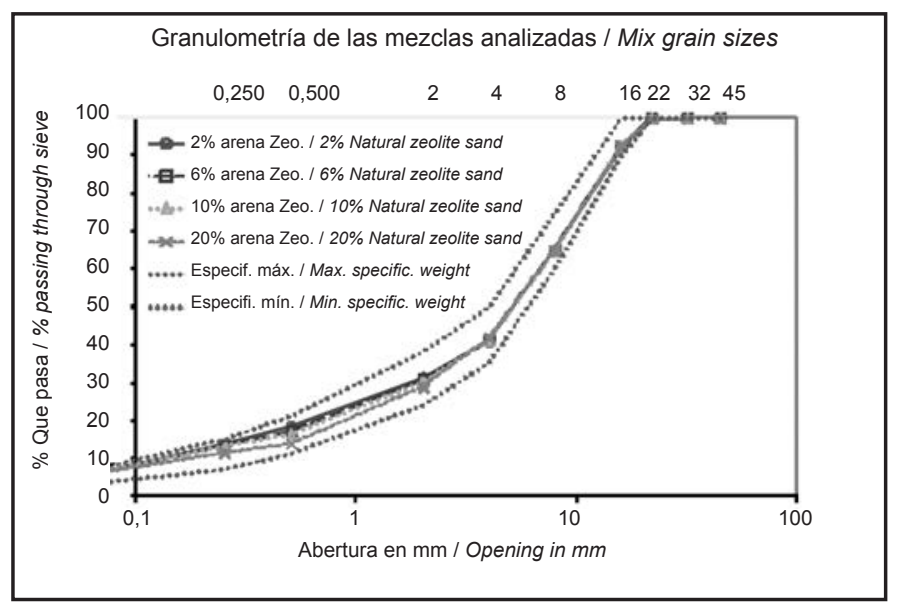

Figura 9. Variación de la granulometría de las mezclas en función del porcentaje de zeolita adicionado. Figure 9. Variation in grain size, depending on the zeolite dosage.

Tabla 7 / Table 7

Variación de las proporciones de los áridos. Variation in the aggregate percentages.

\begin{tabular}{|c|c|c|c|c|c|}
\hline & $\mathbf{0 / 5}$ & $\mathbf{6 / 1 2}$ & $\mathbf{1 2 / 1 8}$ & Zeolita natural / Natural zeolite & Filler \\
\hline Patrón / Reference mix & $31 \%$ & $47.0 \%$ & $14.0 \%$ & & $8.0 \%$ \\
\hline $2 \%$ & $31 \%$ & $41.0 \%$ & $18.0 \%$ & $2.0 \%$ & $8.0 \%$ \\
\hline $6 \%$ & $27 \%$ & $41.0 \%$ & $18.0 \%$ & $6.0 \%$ & $8.0 \%$ \\
\hline $10 \%$ & $23 \%$ & $41.0 \%$ & $18.0 \%$ & $10.0 \%$ & $8.0 \%$ \\
\hline $20 \%$ & $13 \%$ & $41.0 \%$ & $18.0 \%$ & $20.0 \%$ & $8.0 \%$ \\
\hline
\end{tabular}

Tabla 8 / Table 8

Peso específico de los áridos combinados para las mezclas con adición de zeolita natural como arena. Specific weight of combined aggregate for the mixes with natural zeolite sand.

\begin{tabular}{|c|c|c|c|c|c|}
\hline & \multicolumn{5}{|c|}{ Adición de zeolita en arena / Dosage of zeolite sand } \\
\hline & $\begin{array}{c}\text { Patrón / } \\
\text { Reference }\end{array}$ & $\mathbf{2} \%$ & $\mathbf{6 \%}$ & $\mathbf{1 0 \%}$ & $\mathbf{2 0} \%$ \\
\hline $\begin{array}{c}\text { PE áridos combinados / } \\
\text { Combined specific weight of aggregate }(\mathrm{g} / \mathrm{cm} 3)\end{array}$ & 2.83 & 2.79 & 2.77 & 2.75 & 2.69 \\
\hline
\end{tabular}

Este análisis mostró que igualmente podía emplearse zeolita en forma de arena en las mezclas asfálticas para lo cual nos trazamos este segundo objetivo:

b) Evaluar diferentes formas de añadir zeolita manteniendo un $0,3 \%$ de filler (conservando la adición que plantea la bibliografía como referencia). En este caso se analizaron 3 adiciones diferentes: un 0,3\% de filler de zeolita, un $10 \%$ de arena de zeolita de tamaño 0-4 $\mathrm{mm}$, que es el porcentaje de arena con un contenido de filler de $0,3 \%$ y un $1 \%$ de arena fina de zeolita que contendría un 0,7\% de 0,063-0,50 mm de esta arena fin y de igual forma un $0,3 \%$ de polvo.
This analysis showed that zeolite sand could also be used in asphalt mixes. This result was directly linked to the second objective of our study:

b) To evaluate the different ways of adding zeolite with a constant filler dosage of $0.3 \%$ (the reference value in the bibliography). In this case, three different mix designs were analyzed: (i) $0.3 \%$ zeolite filler; (ii) $10 \%$ zeolite sand with a $0-4 \mathrm{~mm}$ grain-size with a filler content of $0.3 \%$; (iii) $1 \%$ fine zeolite sand, $0.7 \%$ of which with a $0.063-0.50 \mathrm{~mm}$ grain size and $0.3 \%$ zeolite filler. 
La adición del 1\% de arena fina se justifica a partir de analizar la granulometría de la zeolita (Figura 3) que muestra que el mayor contenido del aditivo está en los tamaños de 0,5 a $4 \mathrm{~mm}$, por lo que al añadir un $10 \%$ de arena, se obtendría fundamentalmente la influencia de las partículas más grandes del material. Así, añadiendo una cantidad de zeolita $(1,0 \%)$ que contemplara las fracciones más finas del aditivo $(0-0,50 \mathrm{~mm})$, manteniendo el $0,3 \%$ de filler, tendríamos otro criterio de comparación de las diferentes partículas de este material.

Estas mezclas se sometieron al ensayo Marshall así como al ensayo de módulo de rigidez, el cual se llevó a cabo para dos temperaturas $\left(30^{\circ} \mathrm{C}\right.$ y $\left.50^{\circ} \mathrm{C}\right)$. En la Tabla 9 se muestran los pesos específicos correspondientes a estas mezclas.
The addition of $1 \%$ fine sand is justified, based on the analysis of the grain size of the zeolite (Figure 3). The results showed that most of the additive had a grain size of 0.5-4 mm. Consequently, when $10 \%$ sand was added, this highlighted the influence of the largest particles in the material. Accordingly, the addition of a $1.0 \%$ zeolite of finer fractions $(0-0.50 \mathrm{~mm})$, along with the same $0.3 \%$ filler dosage, provided another criterion for comparing the different grain sizes of this material.

The Marshall test was performed on the mixes and the stiffness modulus was also tested for two temperatures $\left(30^{\circ} \mathrm{C}\right.$ and $\left.50^{\circ} \mathrm{C}\right)$. Table 9 shows the specific weights of each mix.

Tabla 9 / Table 9

Peso específico de los áridos combinados para las diferentes mezclas ensayadas. Specific weight of the combined aggregates for the mixes.

\begin{tabular}{|c|c|c|c|c|}
\hline & \multicolumn{3}{|c|}{ Adición de zeolita en arena / Addition of zeolite sand } \\
\hline & Patrón / Reference & $\mathbf{0 . 3 \%}$ filler & $\begin{array}{c}10 \% \text { Arena / } \\
\text { Sand (0-4 mm) }\end{array}$ & $\begin{array}{c}1 \% \text { Arena fina / } \\
\text { Fine sand (0-0.50 } \mathbf{m m})\end{array}$ \\
\hline $\begin{array}{c}\text { PE áridos combinados / Specific weight of combined } \\
\text { aggregates }\left(\mathrm{g} / \mathrm{cm}^{3}\right)\end{array}$ & 2.83 & 2.88 & 2.75 & 2.72 \\
\hline
\end{tabular}

\subsubsection{Influencia del incremento del filler de zeolita}

Tras comprobar que los resultados obtenidos para las mezclas con zeolita en forma de arena, no eran significativamente superiores a los obtenidos en los ensayos con filler, se decidió centrar el estudio en el empleo de la zeolita en forma de filler ya que además constituía un ahorro considerable de material.

Por tanto se decidió evaluar la influencia del aumento del filler de zeolita, para lo cual se compararon tres porcentajes ( $0,3 \% ; 0,6 \%$ y $1 \%)$. Se evaluó la estabilidad Marshall, deformación, densidad, porcentaje de huecos en mezcla y en áridos, tracción indirecta y sensibilidad al agua.

Los datos relacionados con los pesos específicos de los áridos combinados para los diferentes porcentajes de filler de zeolita se muestran en la Tabla 10.

\subsubsection{Zeolite filler dosage}

The test results showed that the performance of zeolite sand mixes was not significantly better than mixes with zeolite filler. It was thus decided to focus on the use of zeolite filler since this also saved on the material used.

Accordingly, mixes with different zeolite filler dosages (0.3\%, 0.6\%, and $1 \%)$ were analyzed and compared. The parameters evaluated were Marshall stability, deformation, density, air voids in the aggregates and the mix, indirect tensile strength, and moisture sensitivity.

Table 10 shows the data related to the specific weight of the combined aggregates for different dosages of zeolite filler.

Tabla 10 / Table 10

Peso específico de los áridos combinados para las mezclas con adición de zeolita natural como filler. Specific weight of the combined aggregates for mixes with different natural zeolite filler dosages.

\begin{tabular}{|c|c|c|c|c|}
\hline & \multicolumn{3}{|c|}{ Adición de filler de zeolita / Zeolite filler dosage } \\
\hline & Patrón / Reference mix & $\mathbf{0 . 3} \%$ & $\mathbf{0 . 6 \%}$ & $\mathbf{1} \%$ \\
\hline $\mathrm{PE}$ áridos combinados / Specific weight of combined aggregates $\left(\mathrm{g} / \mathrm{cm}^{3}\right)$ & 2.83 & 2.88 & 2.84 & 2.82 \\
\hline
\end{tabular}




\section{ANÁLISIS DE LOS RESULTADOS}

\subsection{Comparación de mezclas fabricadas con zeolita sintética y natural}

En la Tabla 11 se muestran los resultados obtenidos de este primer objetivo, referentes a la estabilidad Marshall, deformación, densidad y porcentaje de huecos en la mezcla y en los áridos.

\section{ANALYSIS OF RESULTS}

\subsection{Comparison of mixes manufactured with synthetic zeolite and natural zeolite}

Table 11 shows the results obtained for this first objective in reference to Marshall stability, deformation, densi$t y$, and percentage of voids in the aggregates and mix.

Tabla 11 / Table 11

Resultados de los parámetros Marshall evaluados en las mezclas. Results of the Marshall parameters evaluated in the mixes.

\begin{tabular}{|c|c|c|c|c|c|}
\hline & $\begin{array}{c}\text { Densidad / } \\
\text { Density }\left(\mathrm{g} / \mathrm{cm}^{3}\right)\end{array}$ & $\begin{array}{l}\text { Estabilidad / } \\
\text { Stability (kN) }\end{array}$ & $\begin{array}{l}\text { Deformación / } \\
\text { Deformation } \\
\text { (mm) }\end{array}$ & $\begin{array}{l}\text { Huecos mezclas I } \\
\text { Voids in mix (\%) }\end{array}$ & $\begin{array}{c}\text { Huecos áridos / Voids } \\
\text { in aggregates (\%) }\end{array}$ \\
\hline $\begin{array}{c}\text { Patrón / } \\
\text { Voids in aggregates }\end{array}$ & 2.503 & 15.22 & 2.82 & 3.7 & 14.6 \\
\hline $\begin{array}{c}\text { Zeolita sintética / } \\
\text { Synthetic zeolite mix }\end{array}$ & 2.481 & 11.70 & 2.63 & 4.6 & 15.4 \\
\hline $\begin{array}{c}\text { Zeolita natural / } \\
\text { Natural zeolite mix }\end{array}$ & 2.483 & 11.33 & 2.90 & 6.0 & 16.7 \\
\hline
\end{tabular}

Se observa que al utilizar zeolita en las mezclas la densidad disminuye respecto a la patrón, debido a que la temperatura de fabricación empleada $\left(130^{\circ} \mathrm{C}-140^{\circ} \mathrm{C}\right)$, puede afectar la compactación de la mezcla. En correspondencia con los valores de densidad, se comprobó que el empleo de zeolita afecta el porcentaje de huecos. Este parámetro en la mezcla con la zeolita natural es superior al obtenido con la zeolita sintética. Se comprobó, en este caso, que con la utilización de zeolita en las mezclas la estabilidad disminuye con respecto a la mezcla patrón. La pérdida de resistencia puede estar relacionada con la reducción de la densidad dada por las bajas temperaturas empleadas en el mezclado y la compactación.

La deformación de las mezclas con zeolitas respecto a la mezcla patrón no muestra prácticamente variaciones. La mayor estabilidad corresponde a la mezcla patrón, sin embargo no es la que presenta mayor deformación, por lo que se puede deducir que las mezclas con zeolita son más deformables que la mezcla patrón, por lo cual sería aconsejable profundizar en los estudios sobre las variaciones en la deformación.

\subsection{Adición de zeolita como arena}

\subsubsection{Influencia del incremento de zeolita en forma} de arena

En las Figuras de la 10 a la 14 se muestran los resultados de los ensayos realizados a las mezclas correspondientes al ensayo Marshall (densidad, estabilidad, deformación, huecos mezclas y áridos).
It was observed that the mixes with zeolite had a lower density than the reference mix. This was due to the manufacturing temperature $\left(130^{\circ} \mathrm{C}-140{ }^{\circ} \mathrm{C}\right)$, which can affect mix compaction.In relation to mix density values, it was found that the zeolite affected the percentage of air voids. This parameter in the natural zeolite mix was higher than in the synthetic zeolite mix. Moreover, the zeolite mixes had lower stability values than the reference mix. This loss of strength may be related to their lower density, given the lower mixing and compaction temperatures.

In comparison with the reference mix, the deformation of the zeolite mixes only showed a very slight variation. The reference mix had higher stability, and did not have a greater deformation. Since our results indicate that the zeolite mixes are more susceptible to deformation than the reference mix, it would be advisable to carry out more in-depth studies of the variation in this parameter.

\subsection{Zeolite sand dosage}

\subsubsection{Analysis of mixes with different dosages of zeolite sand}

Figures 10-14 show the results of the tests performed on the mixes. These included the Marshall tests (i.e. density, stability, deformation, and air voids in mix and aggregates). 


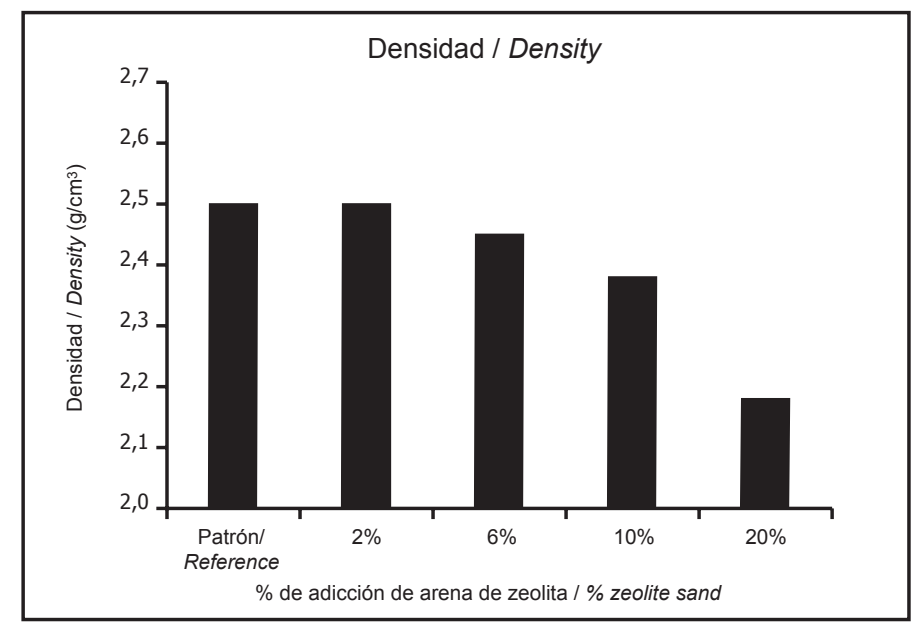

Figura 10. Densidad de las mezclas (arena de zeolita). Figure 10. Density of the zeolite sand mixes.

A medida que aumenta el porcentaje de arena de zeolita natural, disminuye la densidad de las mezclas. Como la zeolita tiene menor densidad que los áridos, por tanto su incremento produce reducción de la densidad de la mezcla. La reducción de la densidad con el aumento de la cantidad de arena de zeolita, está relacionada con el hecho de que la zeolita posee una densidad menor que la arena a la que sustituye en la fórmula de trabajo. La mezcla con $2 \%$ de arena de zeolita no experimenta cambios en la densidad. Posiblemente el incremento de zeolita no es significativo para producir los cambios de densidad.

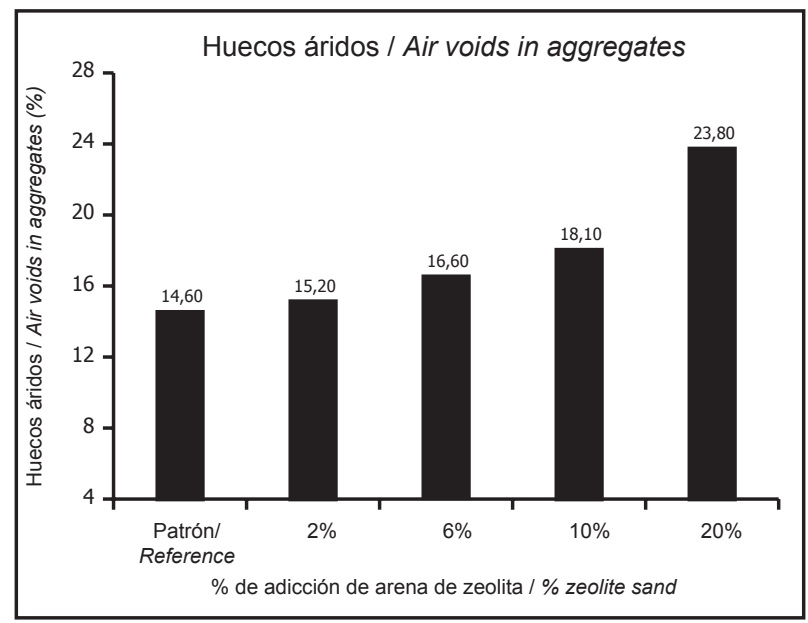

Figura 11. Huecos en los áridos (arena de zeolita). Figure 11. Air voids in aggregates (zeolite sand).

El comportamiento de los huecos (áridos y mezcla) está en correspondencia con los valores de las densidades de las mezclas. A medida que disminuye la densidad aumentan los porcentajes de huecos en la mezcla y en los áridos, a tal punto que para el $20 \%$ de arena, la mezcla no cumple con las condiciones impuestas para soportar las cargas del tráfico más exigentes.
As the percentage of natural zeolite sand increased, this produced a corresponding reduction in the density of the mixes. This is explained by the fact that the zeolite had a lower density than the aggregates or the sand that it replaced in the job mix formula. Nevertheless, the mix with $2 \%$ zeolite sand experienced no change in density. Possibly, such a small increase in zeolite was not sufficient to produce any variation in the density of the mix.

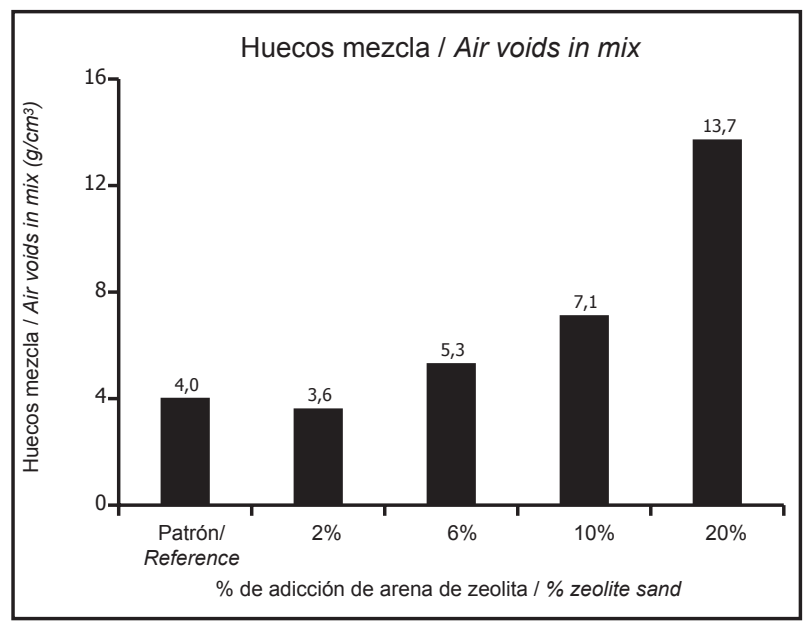

Figura 12. Huecos en la mezcla (arena de zeolita). Figure 12. Air voids in mix (zeolite sand).

The air voids in the aggregates and mix are in consonance with the density of the mixes. As the mixes become less dense, there is a corresponding increase in the percentageof air voids in the mix and aggregates. As can be observed, the mix with a $20 \%$ sand dosage does not meet requirements for the most demanding traffic loads. 


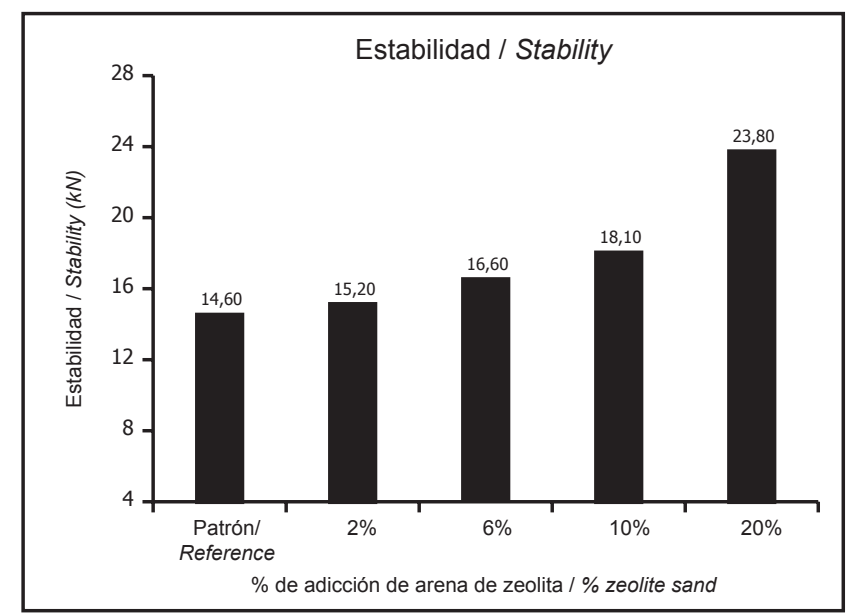

Figura 13. Estabilidad Marshall (arena de zeolita).

Figure 13. Marshall stability (zeolite sand).

Para el tipo de mezcla y contenido de betún ensayado, el aumento de la cantidad de zeolita natural como arena, hace que aumente la estabilidad Marshall de las mezclas hasta el $10 \%$, a partir del cual comienza a disminuir. El incremento de zeolita como arena favorece la estabilidad de las mezclas, llegando a obtenerse incluso valores comparables con la mezcla patrón. Con el aumento de arena se obtuvo un incremento en la estabilidad, de un $2 \%$ a un $10 \%$, a pesar de la reducción de la densidad. Se esperaba que con la disminución de la densidad, en mezclas con igual contenido de betún, y los mismos áridos, también ocurriera una reducción de la estabilidad, lo que sucede solamente para el $20 \%$ de arena. Puede deberse a que al haber un mayor aporte de agua el efecto de espumación generado en la mezcla es mayor y la envuelta y por tanto la cohesión de la misma aumenta, a pesar de que la densidad haya disminuido por el menor peso específico de la zeolita frente a la caliza. Así se obtiene un valor de estabilidad mayor, hasta un cierto valor de adición de arena en el cual disminuye. Este hecho puede estar relacionado con el efecto de espumado que produce la zeolita sobre el betún, aumentando en exceso la cantidad de agua expulsada por el material, lo que dificulta la preparación de la mezcla y por tanto mantener la temperatura de mezclado, lo que afecta a la densidad y la compactación.
For the type of mix and the bitumen content analyzed, a larger dosage of natural zeolite sand increased the Marshall stability of the mixes up to $10 \%$, after which there was a reduction. Zeolite sand thus enhanced the stability of the mixes and even showed values comparable to those of the reference mix. When the sand dosage increased, mix stability rose from $2 \%$ to $10 \%$, despite lower density values. Although a lower mix density with an equal bitumen dosage and the same aggregates was expected to reduce stability, this only occurred in the mix with a $20 \%$ dosage of zeolite sand. Possibly, the higher water contributionaccentuatedthe foaming effect. The coating and the cohesion of the mix thus increased despite the lower mix density, stemming from the lower specific weight of the zeolite in comparison to the limestone. Consequently, stability increased up to a certain zeolite sand dosage after which, it decreased. This could be related to the foaming effect that the zeolite has on the bitumen. When the quantity of water released by the material is excessive, this makes the mix more difficult to prepare and the mix temperature more difficult to maintain, all of which affects the density and compaction of the mix.

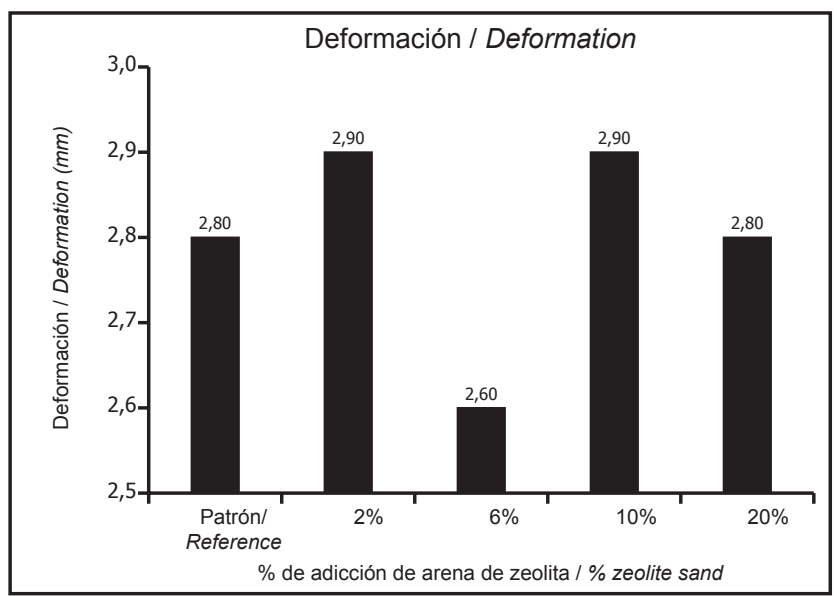

Figura 14. Deformación de las mezclas (arena de zeolita). Figure 14. Mix deformation (zeolite sand). 
La deformación muestra un comportamiento similar para todos los casos de adición de zeolita natural y para la mezcla patrón, manteniéndose en el rango de 2,6 a 2,9mm.

\subsubsection{Comparación de las mezclas con zeolita} añadida como filler y como arena pero con el mismo contenido de filler $(0,3 \%)$

Se presentan a continuación (figura 15 (a) (b) (c) (d) y (e)) los resultados de la densidad, huecos mezcla y áridos, estabilidad Marshall, deformación y módulos de rigidez de las mezclas fabricadas para este epígrafe.
The deformation is similar for all the natural zeolite dosages as well as for the reference mix, and remains within a range of $2.6-2.9 \mathrm{~mm}$.

\subsubsection{Comparison of zeolite sand mixes and zeolite filler mixes with the same filler content $(0.3 \%)$}

Figures 15 ( $a, b, c, d$, e) show the values obtained for mix density, air voids in mix and aggregates, Marshall stability, deformation, and stiffness modulus.

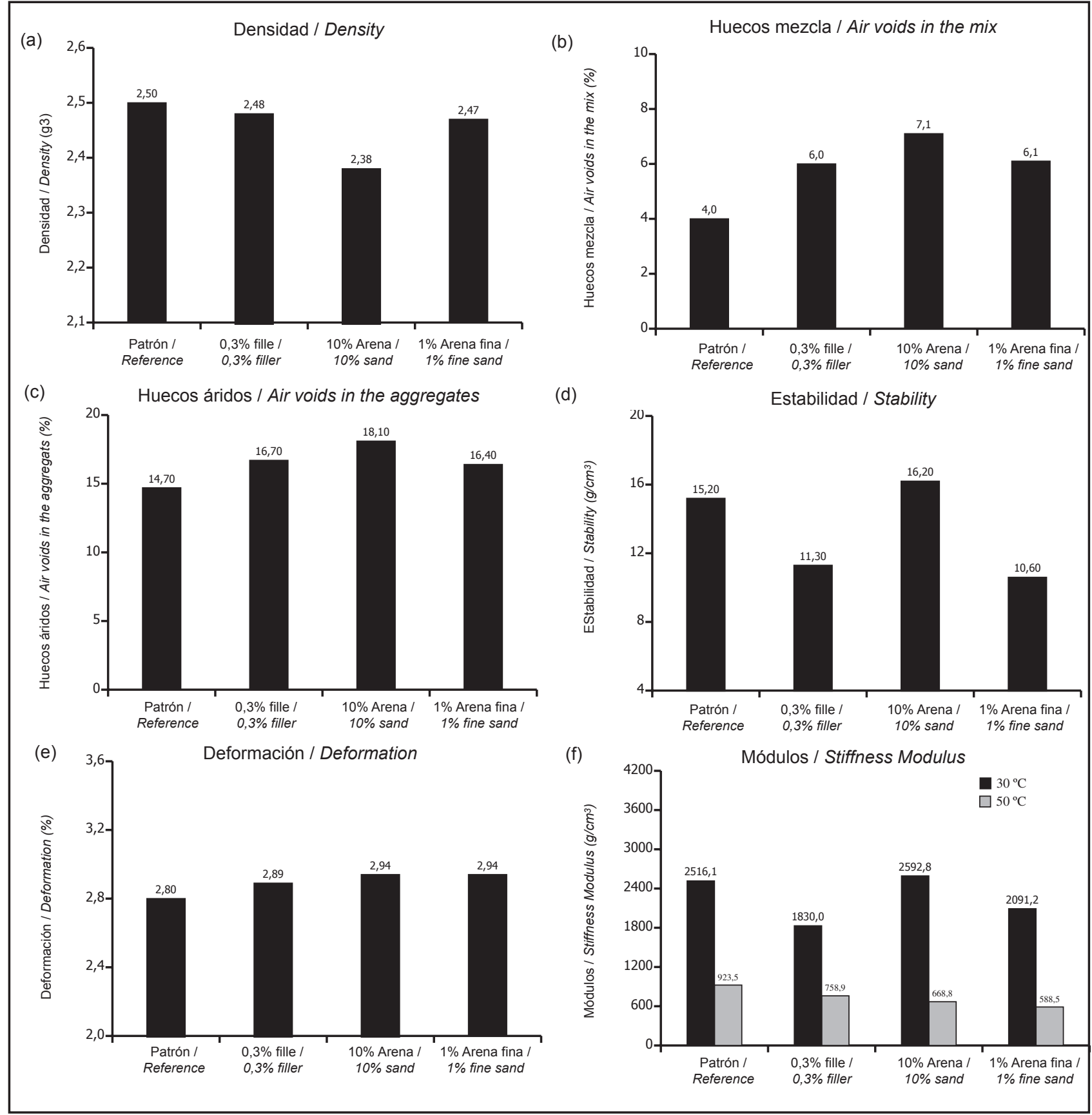

Figura 15. Resultados de los ensayos realizados a las mezclas.

Figure 15. Mix test results. 
Los resultados relativos a la densidad (Figura 15 (a)) corroboran que al añadir zeolita en forma de arena (0-4 mm), la densidad disminuye, debido a que la zeolita tiene menos densidad que la caliza, y al añadirla en mayor porcentaje, sustituyendo además la caliza, se obtiene dicho resultado. En cambio las mezclas con $0,3 \%$ de filler y $1 \%$ de arena fina, no evidencian cambios, una respecto a la otra, por lo que tiene mayor influencia en este parámetro el grano más grueso de la zeolita. Los huecos mezclas y áridos (Figura 15 (b) y (c)) tienen resultados en correspondencia con las variaciones de la densidad.

En cuanto a la estabilidad (Figura 15 (d)), se puede decir que la arena de zeolita (0-4 $\mathrm{mm}$ ) le aporta resistencia a las mezclas, donde influye fundamentalmente los mayores tamaños del material, ya que al añadir la arena fina (0-0,50 mm) se obtienen similares resultados que para la adición de filler solamente. La deformación (Figura 15 (e)) es similar en todos los casos.

En los resultados del módulo de rigidez (Figura 15 (e)) se observa que para $30^{\circ} \mathrm{C}$ el mayor módulo se obtiene con la mezcla a la cual se le adicionó la zeolita como arena, incluso superior a la mezcla patrón, así como que la mezcla con zeolita en forma de filler es la de menor módulo; lo que corrobora la idea de que el aporte en forma de arena favorece la mezcla. Sin embargo, los resultados son diferentes para $50{ }^{\circ} \mathrm{C}$, ya que el mayor valor lo produce el $0,3 \%$ de filler. A partir de estos resultados para condiciones críticas de temperatura $\left(50{ }^{\circ} \mathrm{C}\right)$, el $0,3 \%$ de filler es la adición que muestra mejor comportamiento, y en la que se produjo además la menor reducción del módulo con el incremento de temperatura.

\subsection{Influencia del incremento del filler de zeolita}

Seguidamente se presentan los resultados de los ensayos llevados a cabo para estas mezclas, estabilidad Marshall, deformación, densidad, huecos en la mezcla y en los áridos (Figura 16 (a) (b) (c) (d) y (e)), tracción indirecta tanto en condiciones húmedas y secas (Figura 17 (a) y (b)) y sensibilidad al agua (Figura 18).

Se observa que el incremento de filler de zeolita para el tipo de mezcla y el contenido de betún ensayado, para todos los parámetros ensayados, tiene mejor comportamiento para la adición de $0,6 \%$. En el caso de la densidad (Figura 16a), al añadir 0,6\%, se obtienen valores similares que la mezcla patrón. Como en los análisis anteriores los resultados de los huecos mezclas (Figura 16b) y áridos (Figura 16c) se mantienen en correpondencia con los de las densidadaes, así como para la deformación que no
The results in Figure 15 (a) confirm that when zeolite sand (0-4 mm) is added, mix density decreases because zeolite has a lower density than limestone. In contrast, mixes with $0.3 \%$ filler and $1 \%$ fine sand do not show any changes in respect to each other. Consequently, the coarser zeolite grain size does not affect this parameter. As shown in Figures $15(a, b, c)$, the air voids in the mix and aggregates correspond to the variations in density.

In regards to stability, the results in Figure 15 (d) show that zeolite sand $(0-4 \mathrm{~mm})$ makes the mixes stronger. This is reflected in the amount of the material since adding zeolite sand $(0-0.50 \mathrm{~mm})$ produces the same results as when only filler is added. Deformation (Figure 15e) is similar in all cases.

As can be observed in Figure $15 f$, at $30^{\circ} \mathrm{C}$, the stiffness modulus of the zeolite sand mix is even higher than that of the reference mix. The mix with the lowest modulus is the zeolite filler mix. These results confirm that the use of zeolite sand improves mix quality. However, as can be observed, the results are different at $50^{\circ} \mathrm{C}$ since the high modulus value was obtained by the mix with $0.3 \%$ filler. Based on these results for critical temperature conditions $\left(50{ }^{\circ} \mathrm{C}\right)$, the mix with $0.3 \%$ filler showed the best performance since its stiffness modulus experienced the smallest reduction when the temperature was increased.

\subsection{Zeolite filler dosage}

This section presents the results of the tests performed on these mixes. Figure 16 (a-e) shows the test results for Marshall stability, deformation, density, and air voids in the mix, and aggregates. Figure $17(a, b)$ reflects the results for indirect tensile strength in dry and wet conditions. Finally, Figure 18 shows the results for moisture susceptibility.

Of the mixes in our study, the mix with $0.6 \%$ zeolite filler showed the best performance for all of the parameters tested. As can be observed in Figure 16 (a), the density of this mix had a value similar to that of the reference mix. In the same way as in the previous analyses, the results of the air voids in the mix (Figure 16b) and the air voids in the aggregates (Figure 16c) were in consonance with the density values as well as with the deformation, which did not vary in regards to the reference 


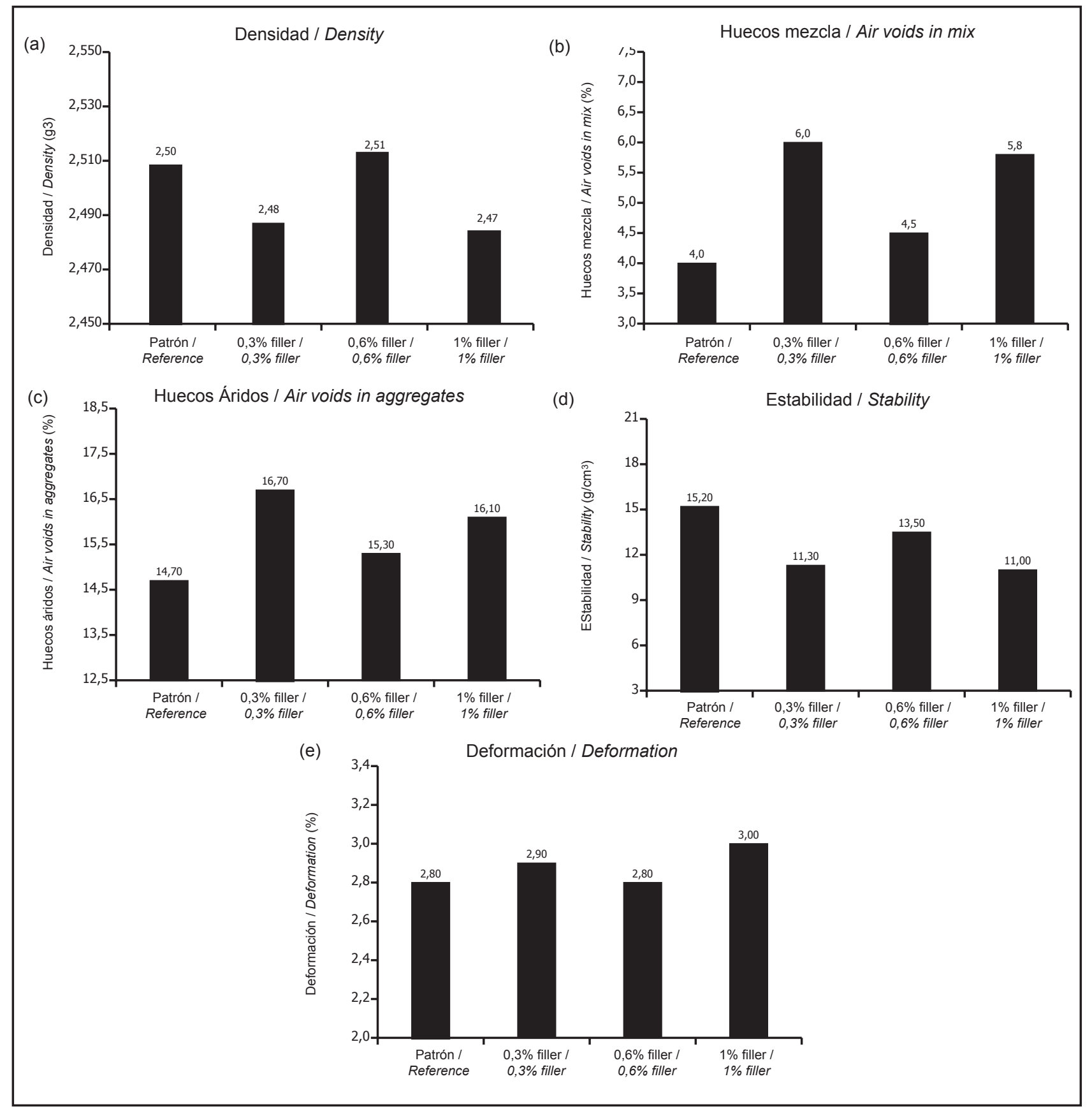

Figura 16. Resultados de los ensayos de densidad (a), porcentaje de huecos en la mezcla (b) y en los áridos (c), estabilidad (d) y deformación (e) de las mezclas ensayadas.

Figure 16. Test results: (a) density; (b) air voids in mix; (c) air voids in aggregates; (d) stability; (e) deformation.

muestra variaciones respecto a la mezcla patrón. Respecto a la estabilidad también se observa un mejor resultado para el $0,6 \%$ de filler, aunque los resultados son inferiores a la mezcla patrón. mix. The stability of the mix with $0.6 \%$ zeolite filler was also acceptable despite the fact that it was slightly lower than that of the reference mix. 


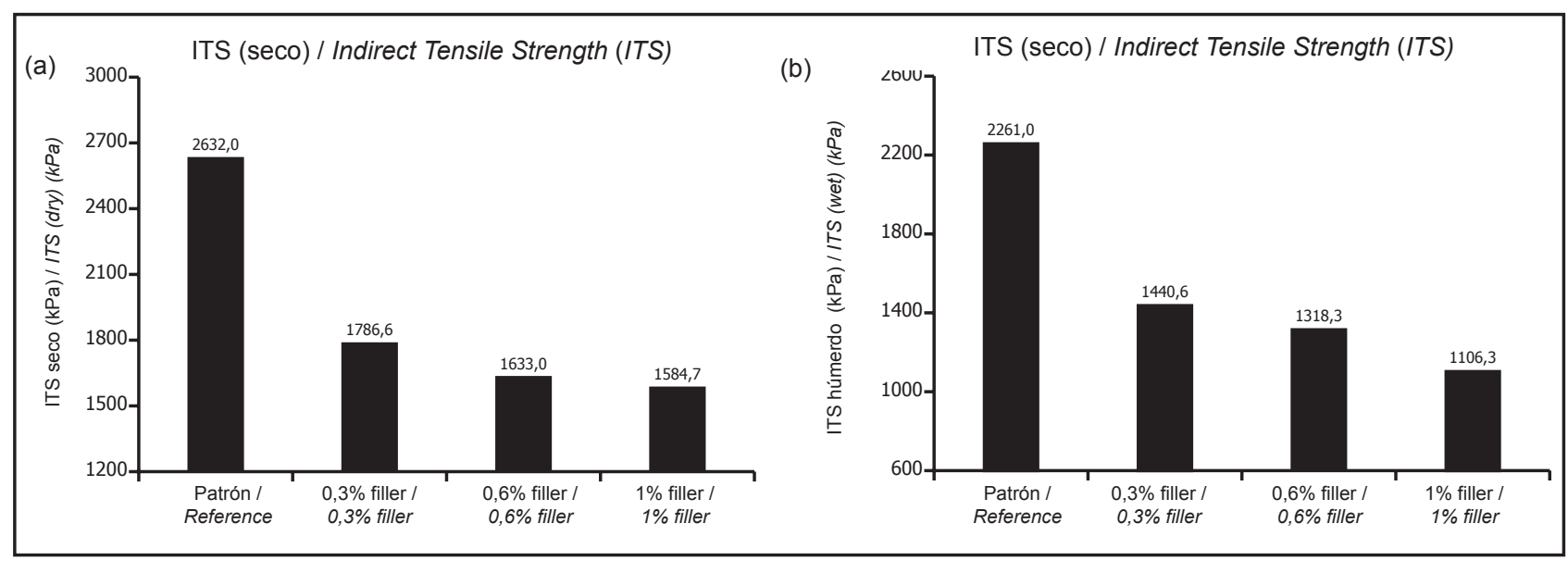

Figura 17. Resistencia a la tracción de las mezclas ensayadas en condiciones húmedas (a) y secas (b). Figure 17. Indirect tensile strength of the mixes: (a) dry conditions; (b) wet conditions.

Se observa una disminución de la resistencia a la tracción indirecta al añadir zeolita natural a las mezclas asfálticas, así como una disminución de la resistencia a tracción a medida que aumenta el contenido de filler, tanto para las probetas ensayadas en seco como en húmedo.
The addition of natural zeolite to the asphalt mixes reduced their indirect tensile strength. This reduction became greater as the filler dosage increased. This was the case for the test specimens both in wet and dry conditions.

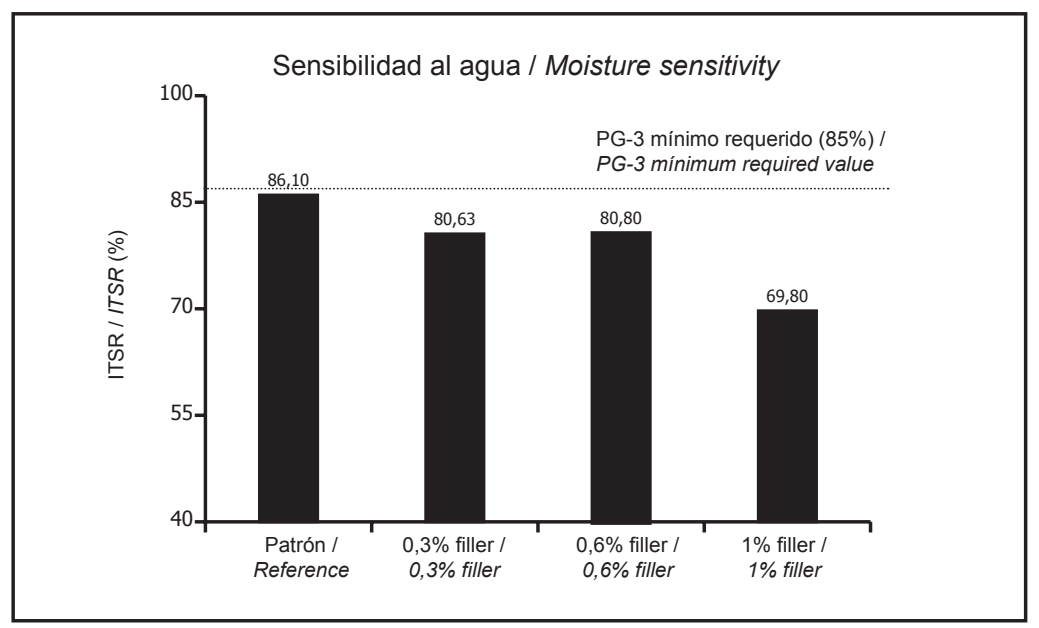

Figura 18. Sensibilidad al agua.

Figure 18. Moisture sensitivity.

El PG-3 (13) establece para mezclas de capa de rodadura un valor mínimo de $85 \%$, se observa que las tres adiciones de zeolita se alejan un poco de este requerimiento, siendo el $0,3 \%$ y el $0,6 \%$ los resultados más cercanos a la especificación. Por lo cual en las mezclas con zeolita natural se pone de manifiesto ciertos problemas ante la presencia de agua, tal y como ya habían apuntado otras investigaciones en torno a mezclas semicalientes (15, 22-24).
The Spanish GeneralTechnical Specifications for Road and Bridge Works (PG-3)(13) requires a minimum moisture sensitivity value of $85 \%$ for asphalt mixes in road surface courses. However, the three zeolite filler mixes did not meet this specification though the $0.3 \%$ and $0.6 \%$ mixes came close to this value. Consequently, natural zeolite mixes pose certain problems in the presence of water, as underlined in other research studies on warm asphalt mixes (15, 22-24). 


\section{CONCLUSIONES}

1. Es posible emplear zeolita natural cubana para el desarrollo de mezclas asfálticas semicalientes dada la similitud de la composición y características con la zeolita sintética y los resultados de los ensayos realizados a mezclas con ambos aditivos.

2. Parece más adecuado añadir la zeolita natural como filler de aportación en la mezcla, ya que los resultados obtenidos en forma de arena no son significativamente muy superiores, lo que representa un ahorro del aditivo. La adición de zeolita natural en forma de arena puede ser empleada siempre que el contenido de aditivo satisfaga, tanto las propiedades de las mezclas como los beneficios medioambientales que representa la utilización de este recurso (zeolita).

3. Para los materiales, mezclas y condiciones de ensayos de esta investigación, los mejores resultados en el ensayo Marshall y sensibilidad al agua (ITSR) fueron para la adición de 0,6\% de filler de zeolita.

4. La cantidad de agua que aporta la zeolita al proceso de espumación (que lógicamente se incrementa con la cantidad de material incorporado), debe ser controlada ya que existe un punto óptimo para cada tiempo y temperatura de mezclado, el cual una vez superado, afecta negativamente al comportamiento de la mezcla. Por tanto, durante el diseño de las mezclas debe determinarse la cantidad óptima de zeolita a incorporar a la mezcla.

A pesar de la profundidad del estudio aquí presentado, resultaría interesante seguir profundizando en el comportamiento de este mineral natural como aditivo para la fabricación de mezclas bituminosas semicalientes. Así, sería bueno analizar la influencia del contenido de betún durante la fase de diseño de las mezclas semicalientes con zeolita natural, su comportamiento a fatiga y a deformaciones plásticas, el empleo en otro tipo de mezclas como son las porosas o discontinuas, o el estudio de aditivos que contrarresten el efecto de la humedad remanente en las mezclas y contribuyan a mejorar la sensibilidad al agua de este tipo de mezclas.

\section{CONCLUSIONS}

1. Cuban natural zeolite can be used in warm asphalt mixes given the fact that its composition and characteristics are similar to those of synthetic zeolite as shown in the test results.

2. Natural zeolite should be added to the mix as filler material since the results obtained when the zeolite is added in the form of sand are not significantly better. Using this material as filler has the additional advantage of saving on additives. However, zeolite sand can be used as long as its dosage does not have a negative effect on the properties of the asphalt mix and as long as its use is beneficial to the environment.

3. Regarding the materials, mixes, and experimental design of this research, the best results for the Marshall Test and moisture sensitivity (ITSR) were obtained by the mix with $0.6 \%$ zeolite filler.

4. The water released by the zeolite, which accentuates the foaming process of the bitumen, should be controlled since there is an optimal point for each time and temperature of the mix. Once this point has passed, the performance of the mix is negatively affected. Consequently, in the design of the job mix formula, it is necessary to determine the optimalzeolite dosage.

Despite the in-depth study presented in this article, further research should be carried out on this mineral and its use in warm bituminous mixes. In regards to the job mix formula of warm mixes with natural zeolite, it would be interesting to analyze the impact of variations in the bitumen dosage. Other aspects that should be tested are the response of these mixes to fatigue as well as to plastic deformations. Alternativey, the use of natural zeolite could be studied in other mix types such as porous or discontinuous mixes. Finally, it is necessary to explore the use of additives that would counteract the effect of the residual moisture, and thus improve the moisture sensitivity of warm mixes with natural zeolite.

\section{BIBLIOGRAFÍA / BIBLIOGRAPY}

(1) Goh, S., You, Z., Van Dam, T.J.: "Laboratory Evaluation and Pavement Design for Warm Mix Asphalt". Proceedings of the 2007 Mid-Continent Transportation Research Symposium, Center for Transportation Research and Education. Iowa State University, Ames, Iowa (2007).

(2) EAPA: "Low Temperature Asphalt". Rue de Commerce 77. B-10040 Brussels. Position Paper. http://www.eapa.org/usr_img/position_paper/low_temperature_asphalt2005 (2005).

(3) EAPA: "The use of Warm Mix Asphalt". Rue du Commerce 77, 1040 Brussels, Belgium. www.eapa.org. info@eapa.org (2009).

(4) Del Val, M. A.: "Consideraciones ambientales sobre las mezclas asfálticas. Reciclado de mezclas semicalientes". Panorama Actual de las Mezclas Bituminosas, Madrid (2005). 
(5) Wayne, J.P.E.: "Warm Mix Asphalt Pavements: Technology of the future?" (2004).

(6) D’Angelo, J., Jarm, E., Bartoszed, J., Baumgardner, G., Corrigan, M., Cowsert, J., Harman, T., Jamshidi, M., Wayne, J., Newcomb, D., Prowell, B., Sines, R., Yeaton, B.: "Warm-Mix Asphalt: European Practice; International Technology Scanning Program" (FHWA-PL-08-007). FHWA-HPIP, U.S. Department of Transportation. Washington, DC, USA. www.international.fhwa.dot.gov (2008).

(7) Von Devivere, M., Barthel, B., Marchand, J-P.: "Warm Asphalt Mixes by adding Aspha-min $®$ a Synthetic Zeolite". Proceedings of the 22nd World Road Congress, PIARC. Durban, South Africa (2003).

(8) Romier, A., Audeon, M., David, J., Martineau, Y., Olard, F.: "Low Energy Asphalt with the performance of Hot-Mix Asphalt". Journal of the Transportation Research Board". No. 1962. Transportation Research Board, National Academies, Washington D.C. p. 101-112 (2004).

(9) Reyes-Ortiz. O., Pérez. F., Miró. R., Amorós. J., Gil. S. "El Proyecto Fénix en la UPC. Mezclas semicalientes". XV Congreso Ibero- Latino Americano del Asfalto. Lisboa(2009), pp. 1-10.

(10) Hurley, G., Graham, C., Prowell, B.: "Evaluation of Aspha-Min ${ }^{\circledR}$ for use in Warm Mix Asphalt". National Center for Asphalt Technology. NCAT Report 05-04. National Center for Asphalt Technologies, Auburn University (2005).

(11) Hirsch, V.: "Warm Mix Asphalt Technologies". BASt, Germany, Presentation to WMA Scan Team (2007).

(12) Harnischfeger, S.: "Aspha-min Retrospectives and Prospects". BASt, Germany, Presentation to WMA Scan Team (2007).

(13) Jones, C., West, R., Julian, G., Taylor, A., Kvasnak, A.: "Evaluation of Warm Mix Asphalt in Walla Walla, Washington". NCAT Report 11-06. National Center for Asphalt Technologies, at Auburn University (2011).

(14) Bueche, N.: "Warm Asphalt Bituminous Mixtures with regards to energy, emissions and performance". Laboratoire des Voies de Circulation (LAVOC), Ecole Polytechnique Fédérale de Lausanne (EPFL), Switzerland (2009).

(15) Zaumanis, M.: "Warm Mix Asphalt Investigation". Master of Science Thesis. Technical University of Denmark. Department of Civil Engineering (2010).

(16) Ministerio de Fomento. Dirección General de Carreteras: "Pliego de Prescripciones Técnicas Generales para Obras de Carreteras y Puentes PG-3", Ediciones Liteam, Madrid (2004).

(17) Prowell, B.D.: "Warm Mix Asphalt. The International Technology Scanning Program, Sumary Report". http://international.fhwa.dot.gov/ pubs/wma/summary.cfm (2007).

(18) Gutiérrez, M.: "Planta compacta potabilizadora de aguas superficiales con zeolita". Instituto Superior Politécnico José Antonio Echeverría, Cuba. www.zeocat.es/docs/aguapotabilizadora.pdf

(19) Zeolita: ¿Dónde está el mineral del siglo?, in Juventud Rebelde: Santa Clara, Villa Clara (2007).

(20) Márquez, E., Gutiérrez, M.: "Características de las zeolitas cubanas como material filtrante". Revista tecnológica del agua, vol. 135 (1995).

(21) Bascuñan, C., Soca, M.: "Zeolitas y su uso en diferentes ramas de la industria". http://www.bvsde.ops-oms.org/bvsacd/ scan2/032752/032752-00.pdf (1997).

(22) Vaitkus, A., Cygas, D., Laurinavicius, A; Perveneckas, Z.: 2Analysis and evaluation of possibilities for the use of Warm Mix Asphalt in Lithuania2. The Baltic Journal of Road and Bridge Engineering., vol. 4, no. 2 (2009), pp. 80-86. http://dx.doi.org/10.3846/1822427X.2009.4.80-86

(23) Xiao, F., Amirkhanian, S.: "Effects of liquid antistrip additives on rheology and moisture susceptibility of water bearing warm mixtures". Constr. Build. Mater, vol. 24. no 9 (2010), pp 1649-1655. http://dx.doi.org/10.1016/j.conbuildmat.2010.02.027

(24) Hurley, G.C., Prowell, B.D., Kvasnak, A.: "Ohio field trial of Warm Mix Asphalt technologies: construction summary". NCAT Report $09-04$. National Center for Asphalt Technologies, at Auburn University (2009). 